Variations tibétaines, Et autres...

\title{
Skirting the Bodhisattva: Fabricating Visionary Art
}

Habiller le bodhisattva : la fabrique d'un art visionnaire

Rob Linrothe

\section{(2) OpenEdition}

\section{Journals}

Electronic version

URL: https://journals.openedition.org/emscat/1803

DOI: 10.4000/emscat.1803

ISSN: 2101-0013

\section{Publisher}

Centre d'Etudes Mongoles \& Sibériennes / École Pratique des Hautes Études

Electronic reference

Rob Linrothe, "Skirting the Bodhisattva: Fabricating Visionary Art", Études mongoles et sibériennes, centrasiatiques et tibétaines [Online], 42 | 2011, Online since 20 December 2011, connection on 13 July 2021. URL: http://journals.openedition.org/emscat/1803; DOI: https://doi.org/10.4000/emscat.1803

This text was automatically generated on 13 July 2021.

(c) Tous droits réservés 


\section{Skirting the Bodhisattva: Fabricating Visionary Art}

Habiller le bodhisattva : la fabrique d'un art visionnaire

\section{Rob Linrothe}

"Go into this great tower containing the adornments of Vairocana and look-then you will know how to learn the practice of enlightening

beings..." Then Sudhana respectfully circumambulated the enlightening being Maitreya and said, "Please open the door of the tower, and I will enter." Then Maitreya went up

to the door of the tower containing the adornments of Vairocana, and with his right hand snapped his fingers; the door of the tower opened, and Maitreya bade Sudhana to enter. Then Sudhana, in greatest wonder, went into the tower. As soon as he had entered, the door shut.

(Cleary 1989, p. 365)

1 The thresholds of the eastern and western towers of the Buddhist complex at the agricultural village of Mangyu bear an uncanny resemblance to the one described in the quoted text. This essay explores the possibility that the resemblance was intentional on the part of the 12th-century builders in Ladakh, on the far western reaches of cultural Tibet. It also examines the inevitable divergences in the effects of a Buddhist sūtra (composed in Sanskrit but translated into Tibetan) and the architectural structure. The sūtra, with its frequent references to the simultaneity of past, present, and future, succeeds in unhinging customary linear temporal experience as preparation for greater insights. The eastern tower as built is approximately $2 \times 2.2 \times$ 4.96 meters, dominated by a single, 4.5-meter high sculpture of a bodhisattva, with intricate narrative scenes painted on the bodhisattva's dhoti (skirt) and a dense program of icons on the other three walls. ${ }^{1}$ Physical entry into the space suddenly 
delivers an intensified experience of spatial self-consciousness. With its disruptions and deconstructions of normative scale and proportion, the phenomenological experience of the pilgrim is, like Sudhana's, creatively disorienting. Inspired by the narrative and affective power of the Gandavyūha Sütra (hereafter: GS), the tower's designers and artists may have attempted to convey to the ordinary pilgrim a finely tuned correlation in sensory form of the paradigmatic pilgrim's attainment of enlightenment beyond ordinary consciousness. This alone perhaps has the power to explain both the eastern tower's highly unusual configuration of building, sculpture, and painting (distinctive to ca. 12th-century sites in Ladakh), and the specific iconographic program of the bodhisattva's dhoti. Until now, this building type has not been accounted for, nor has the narrative on the dhoti been fully identified.

The village of Mangyu where the complex of shrines was built is located near the more famous site of Alchi in the ancient kingdom of Ladakh. At Mangyu, there are two adjacent main shrines with sculptures and mandala paintings, and at either end, two towers of slightly different sizes housing bodhisattvas. (See figs 1-6). Nearby, are two entrance chörtens (stūpas). These are all found on the northern edge of a small village on top of a ridge overlooking a tributary to the south bank of the Indus River. ${ }^{2}$ The artwork can be classed among what has been termed the "Alchi group of monuments." This group of paintings and sculptures has been dated to the $12^{\text {th }}$ and early $13^{\text {th }}$ centuries, and are closely related to artists working in a Kashmiri style. The artists may even have themselves been Kashmiri, though the donors and patrons, depicted at each site, were undoubtedly local Ladakhi-Tibetans. ${ }^{3}$

Fig. 1. Front façade of the main Mangyu complex; eastern tower on the right, with entrance from the porch

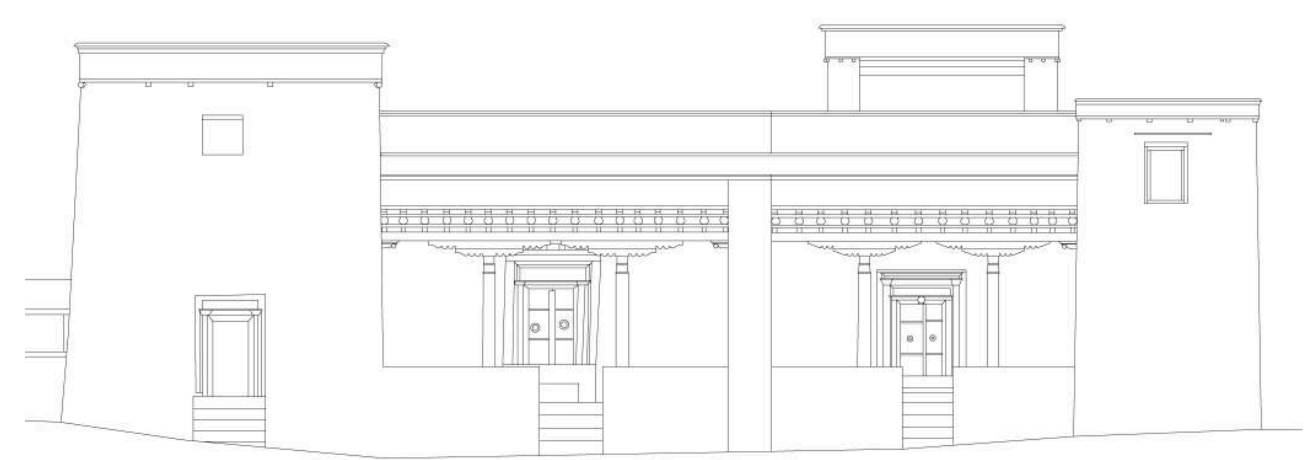


Fig. 1a. Cross-section of the main Mangyu complex; eastern tower on the right, with height of entrance indicated with broken lines
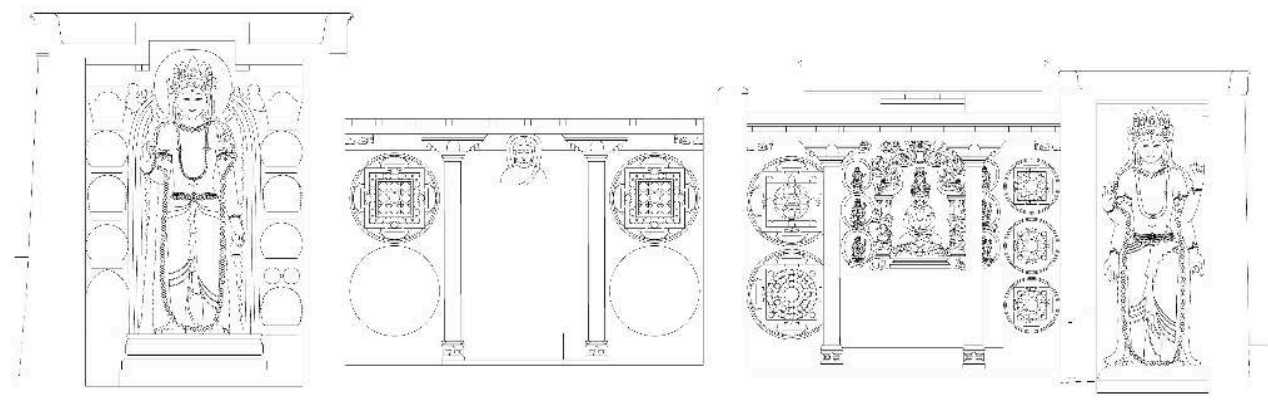

Courtesy of Gerald Kozicz

Fig. 2. Plan of the main Mangyu complex; eastern tower on the right

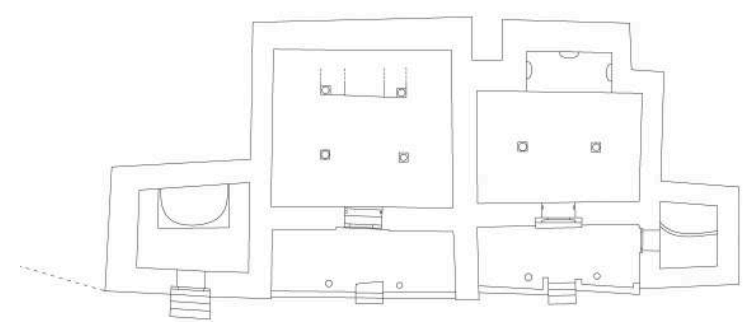

Courtesy of Gerald Kozicz 
Fig. 3. Axonometric drawing of the main Mangyu complex, with western (left) and eastern (right) towers

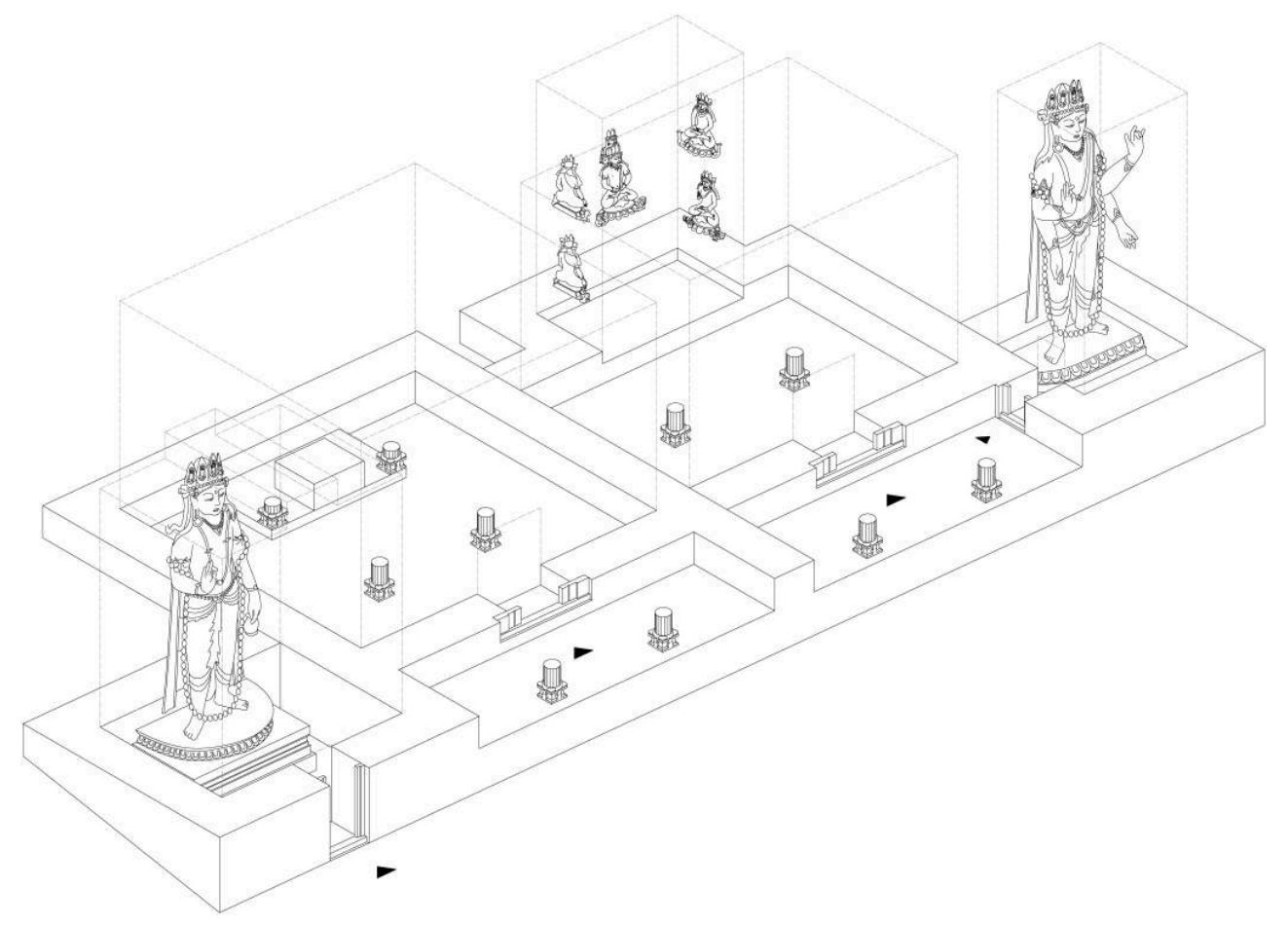

Courtesy of Gerald Kozicz

Fig. 4. Mangyu eastern tower from in front of the entrance to the main complex

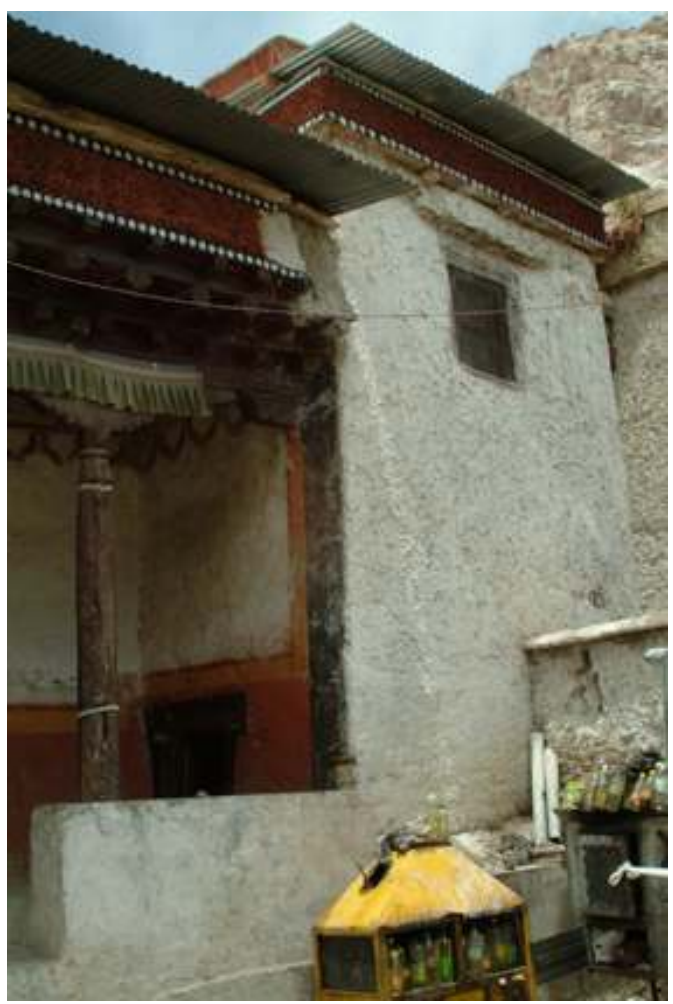

Photo: Rob Linrothe 
Fig. 5. Axonometric drawing of the eastern tower with the four-armed Maitreya sculpture

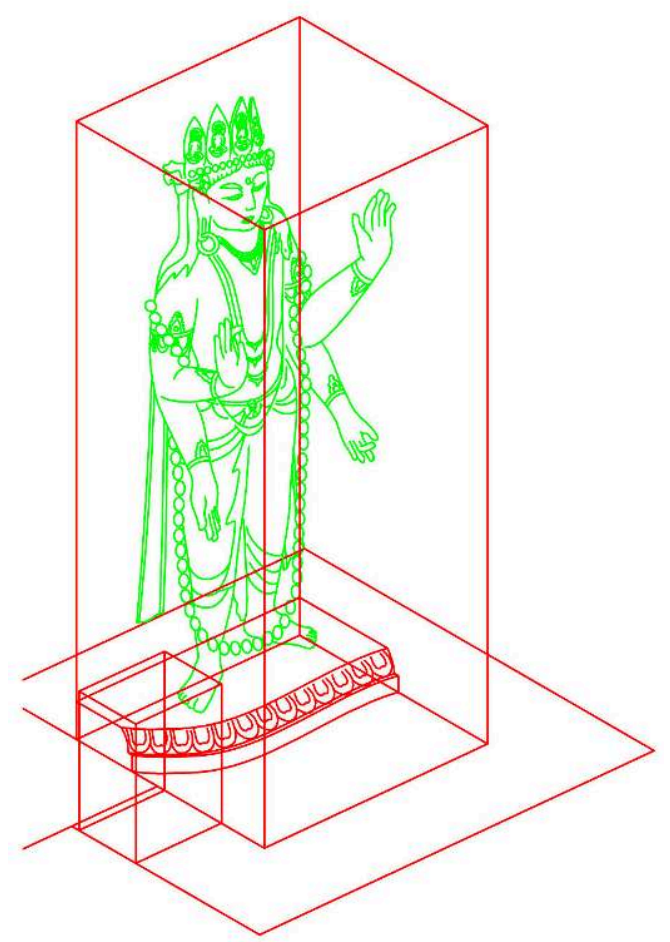

Courtesy of Gerald Kozicz

Fig. 6. Doorway to the Mangyu eastern tower

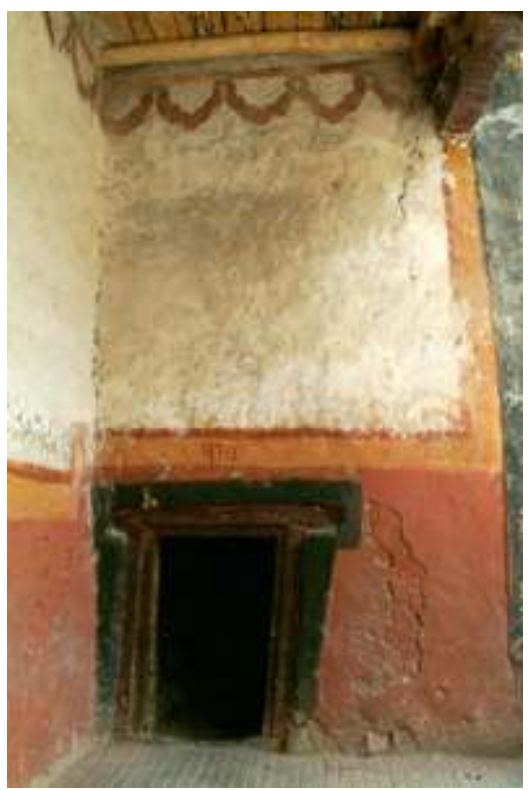

Photo: Rob Linrothe

3 The eastern tower of the Mangyu complex, on the right while facing the entrance to the two side-by-side shrines, is dominated by a sculptural four-armed bodhisattva (fig. 7). Painted on the wall flanking the bodhisattva are the Thousand Buddhas of the Bhadrakalpa (present virtuous age) surrounding panels enclosing images of the four- 
armed Mañjuśrī on the main sculpture's proper right (figs. 8-9) and a four-armed Avalokiteśvara on the left (figs. 10-11). On the wall opposite the sculpture is a third painted panel depicting Kaśmīri-style stūpas (fig. 12), badly marred by water drips from the open window. The standing figure, like the Alchi Sumtsek four-armed two-story Maitreya sculpture, wears a five-Buddha crown (fig. 13) and has been identified as Maitreya. ${ }^{4}$ The presence nearby him of the painted stūpas, an attribute often associated with Maitreya, helps support this identification, as do the representational scenes on the dhoti and the close overall resemblance to the monumental Maitreya sculpture at the Alchi Sumtsek whose identity is not in doubt. ${ }^{5}$

Fig. 7. The four-armed Maitreya sculpture in eastern tower

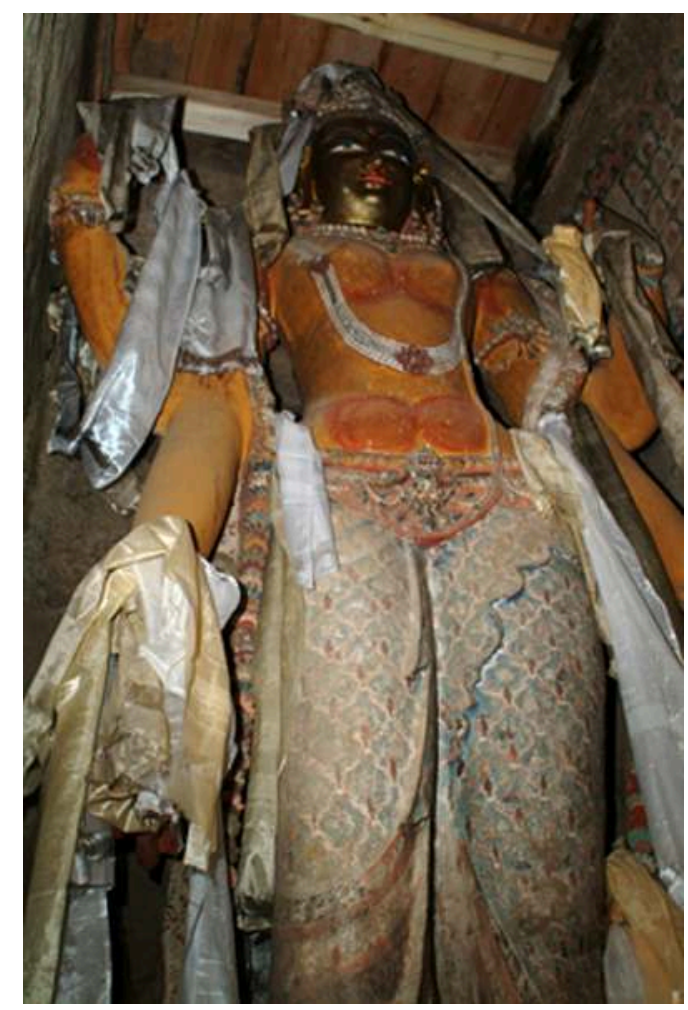

Photo: Rob Linrothe 
Figs. 8-9. Four-armed Mañjuśrī painted on wall next to Maitreya
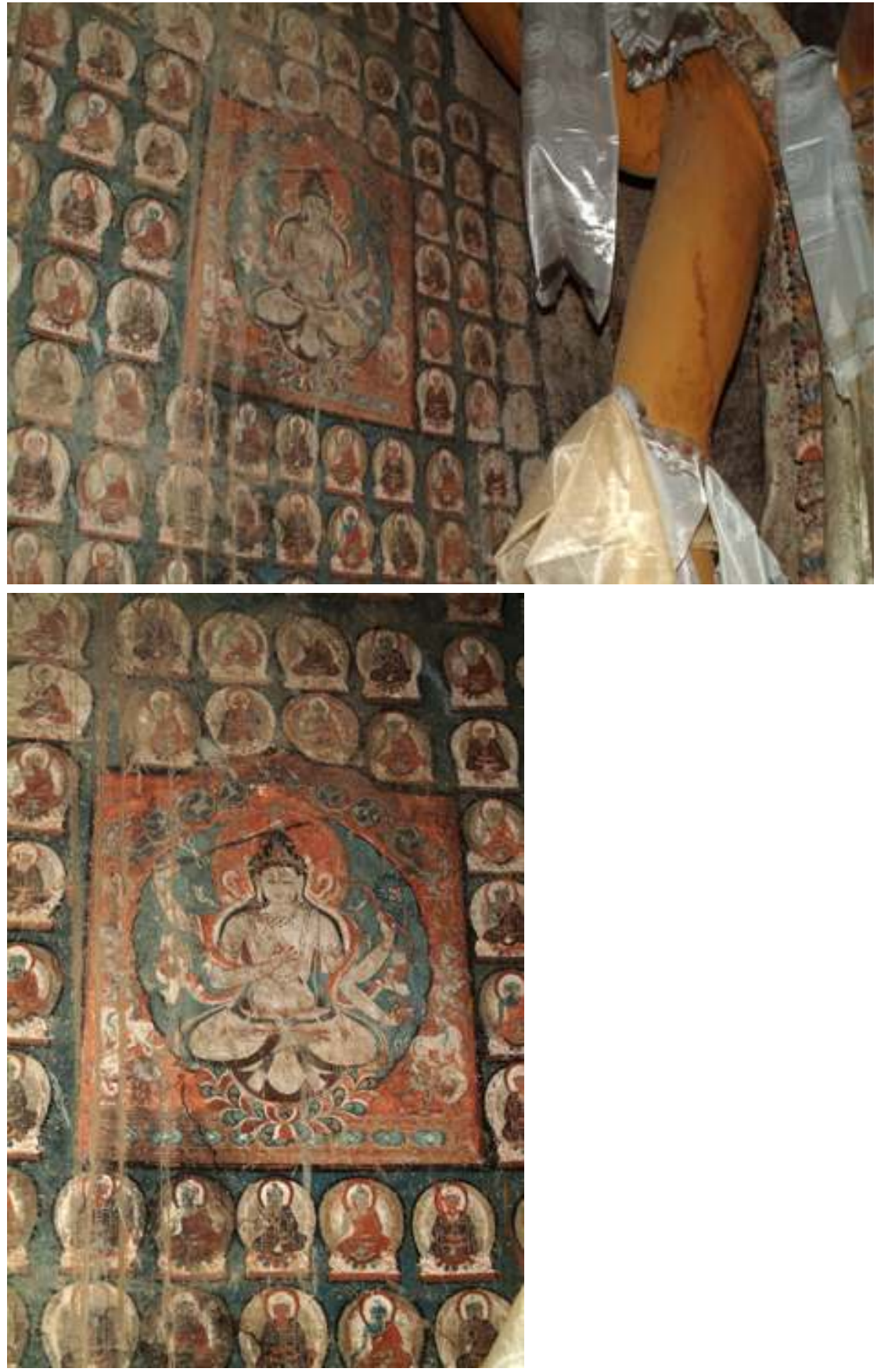

He bears the sword in an upper right hand, an arrow in the second right hand, a bow in the upper left hand, and the stem of a blue utpala-lotus in the lower left hand

Photos: Rob Linrothe 
Fig. 10-11. Four-armed Avalokiteśvara painted on wall next to Maitreya
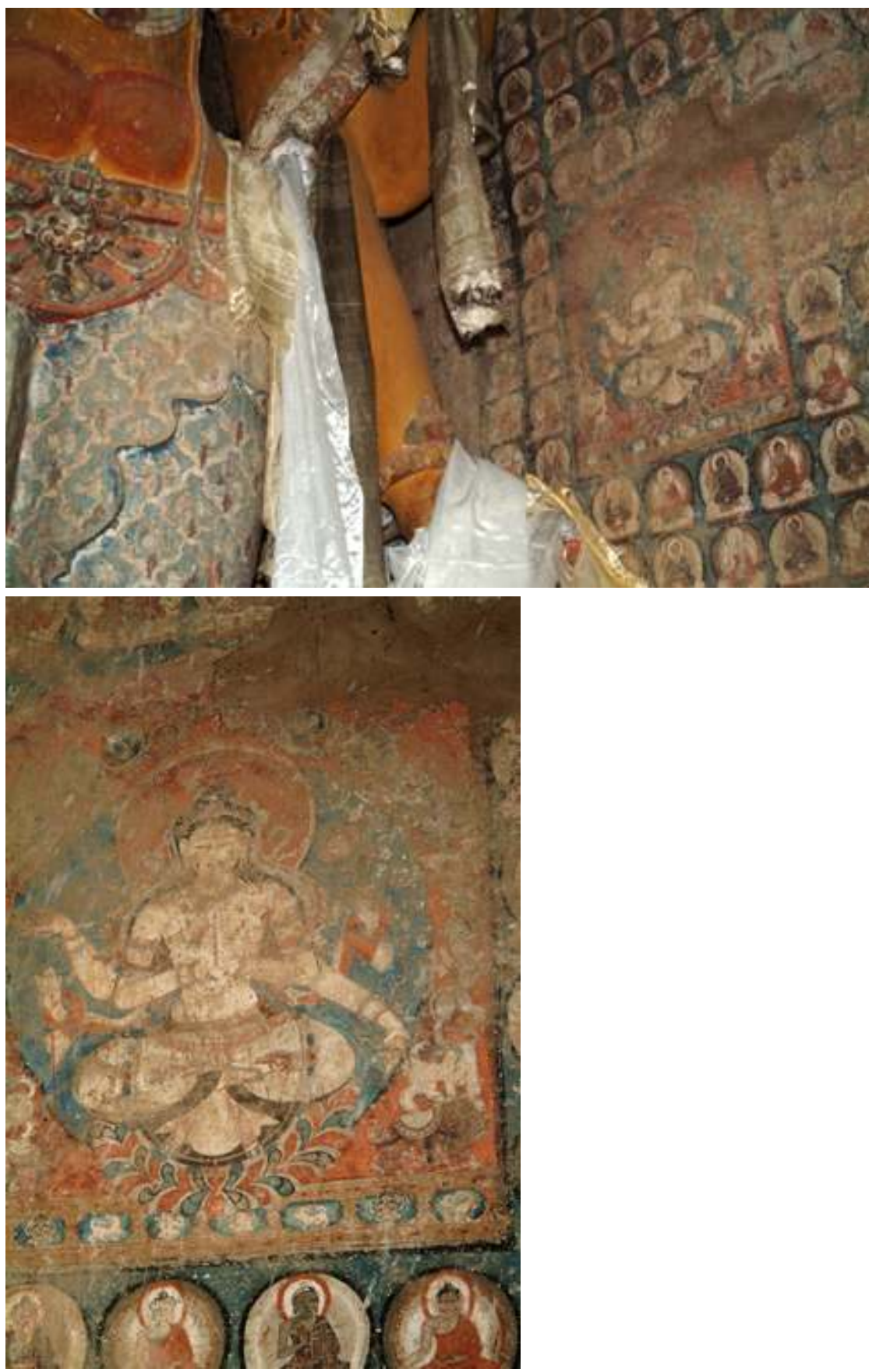

He is in the standard cross-legged pose and makes the añjali mudrā at center, holds a rosary in the second right hand, and the stem of a pink lotus blooming at his shoulder in the second left hand Photos: Rob Linrothe 
Fig. 12. Kaśmīri-style stūpa, one of three painted on wall opposite Maitreya sculpture

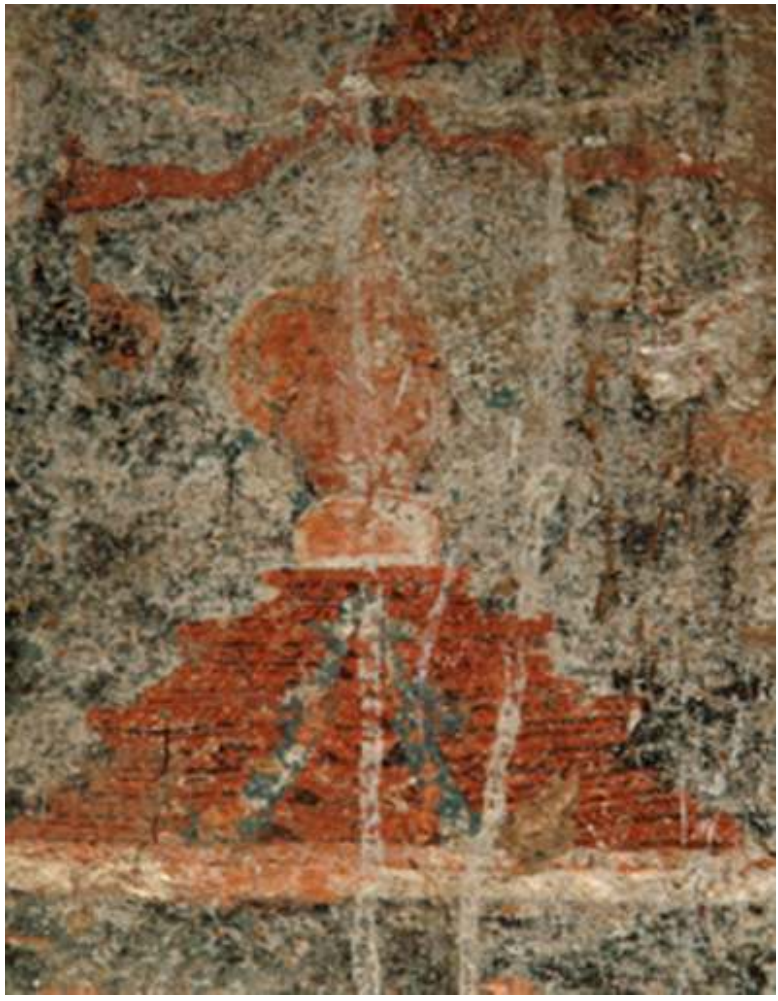

Photo: Rob Linrothe

Fig. 13. Detail of head of Maitreya sculpture

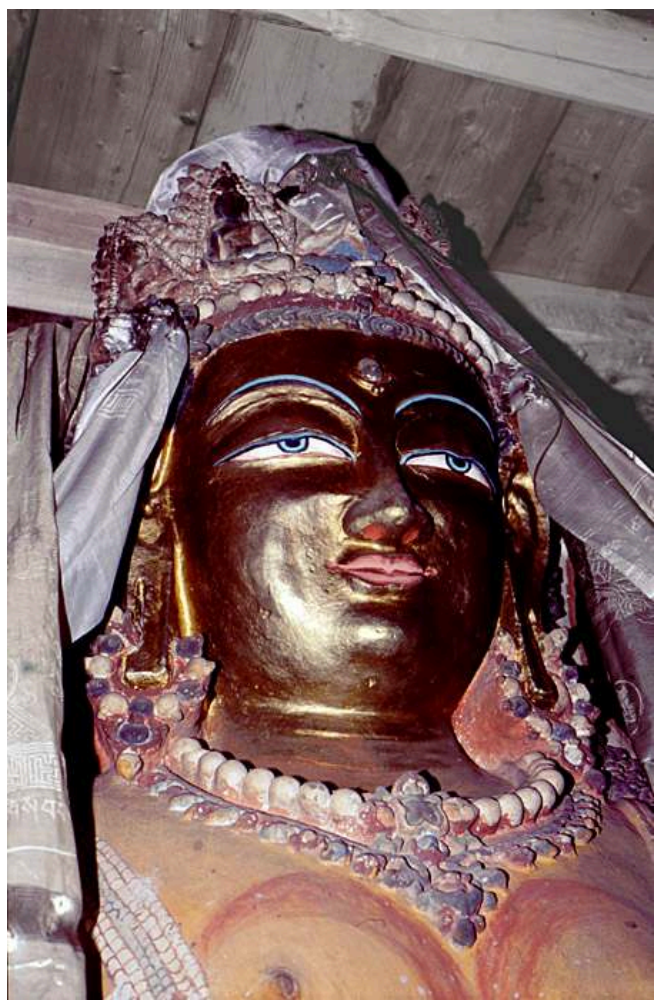

Photo: Peter van Ham 
The focus of discussion here is the dhoti and the themes represented on it (figs. 14-15). The sky-blue ground, mottled and pale except at the edges and crevices, wraps around the front of both legs, with garment folds indicated by ropelike three-dimensional additions. The effect is a very complex series of intersecting planes, especially in the central area between the legs. The upper edges of the painted garment at the hips, just below the right knee, between the legs, and along the left shin, are demarcated with narrow hemlike borders. ${ }^{6}$ These are painted with the same vocabulary of hybrid animals and scrolling devices found in the textile vocabulary at Alchi and Sumda. Within the borders of the hems, and against the blue ground is a repetitive framing device, which Christiane Papa-Kalantari, following James Trilling, calls the "medallion style." The basic structure of the pattern is a rounded diamond or rhomboid shape, formed by four winged griffinlike bodies alternating in pink and white colors (fig. 16). At the top of each diamond, where the two griffins (or vyāla) meet, they share a single head en face, on which are perched the rear legs of the pair forming the enclosure above. The lower griffins share heads with the griffins of the adjacent enclosure, the horizontal interlocking device. Inside each frame, at the bottom, a fleur-de-lis-like shape extends into the enclosed space, partially formed from joining the scrolling tails of the griffins. The pairs of griffins face opposite directions, the two upper ones turning inward and the two lower ones outward. Their pairs of legs are correspondingly manipulated, with the front legs of the two upper griffins turning outward and the back legs facing in, and the opposite for the lower pair. This impulsive, playful joining and adorning seems to be characteristic of Indian artists to create pleasure through visual punning, one of the forms taken by the aesthetic category of alamkāra (to complete or perfect through ornamentation). It is visible at the Ajanta caves of the 5th century and all the way back to Indus Valley seals of the second millennium BCE. It is also found in the decoration of the Dunkar caves in Ngari from around the same time (fig. 17), also in the Kaśmīri-Tibetan style. 
Fig. 14. Painted dhotī of the Maitreya sculpture

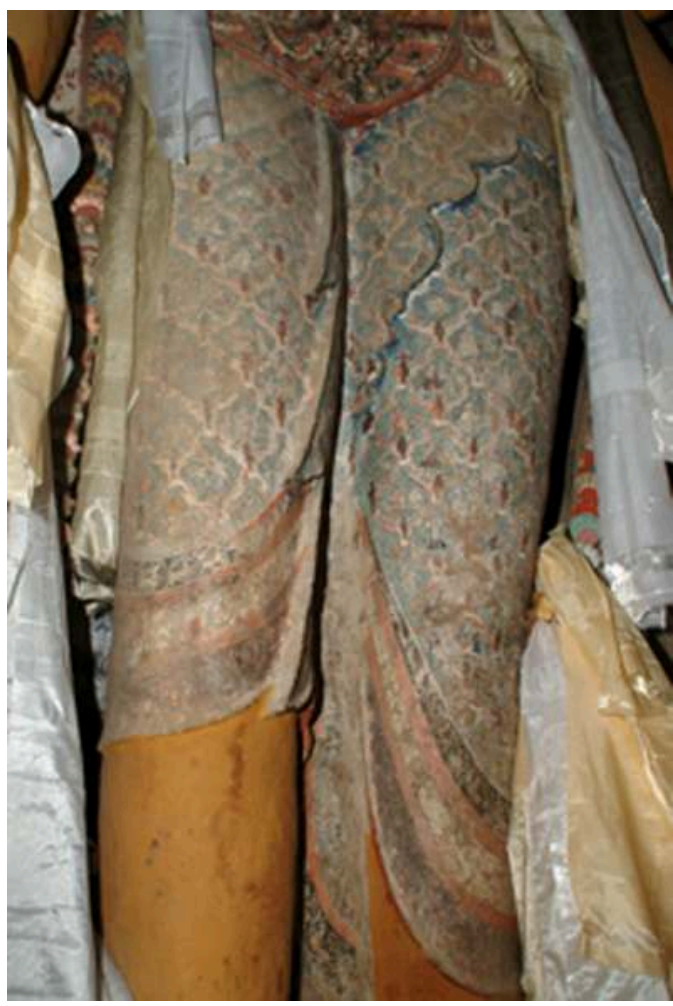

Photo: Rob Linrothe

Fig. 15. Drawing of the plan of the painted dhotī

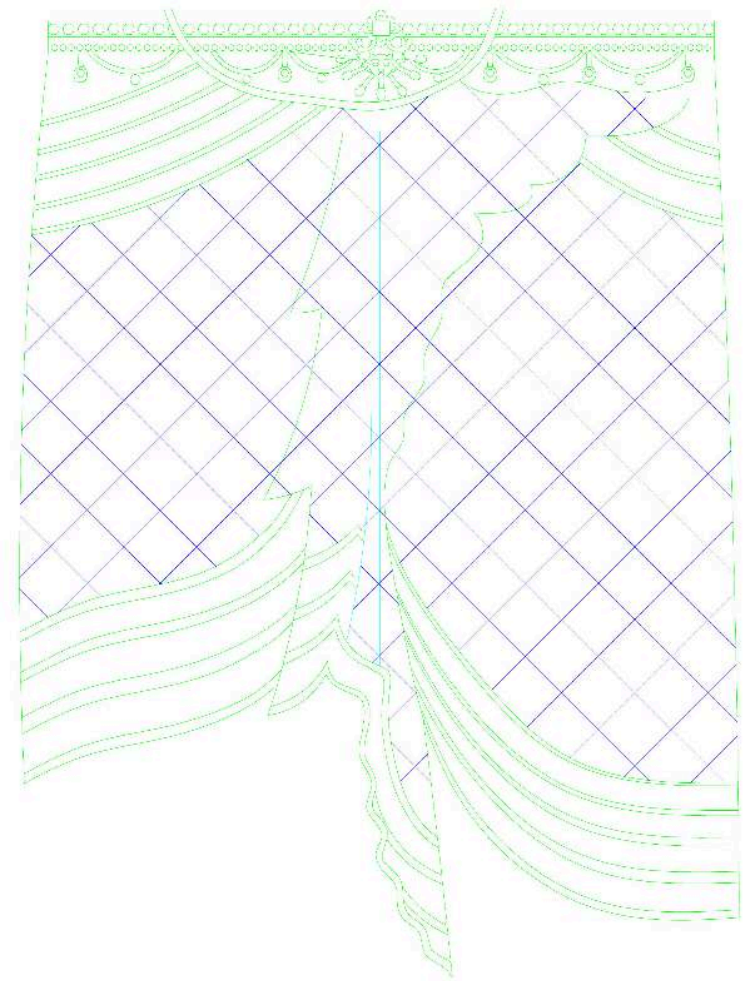

Courtesy Gerald Kozicz

Études mongoles et sibériennes, centrasiatiques et tibétaines, 42 | 2011 
Fig. 16. Drawing of an isolated lozenge-pattern of the Maitreya sculpture dhotī

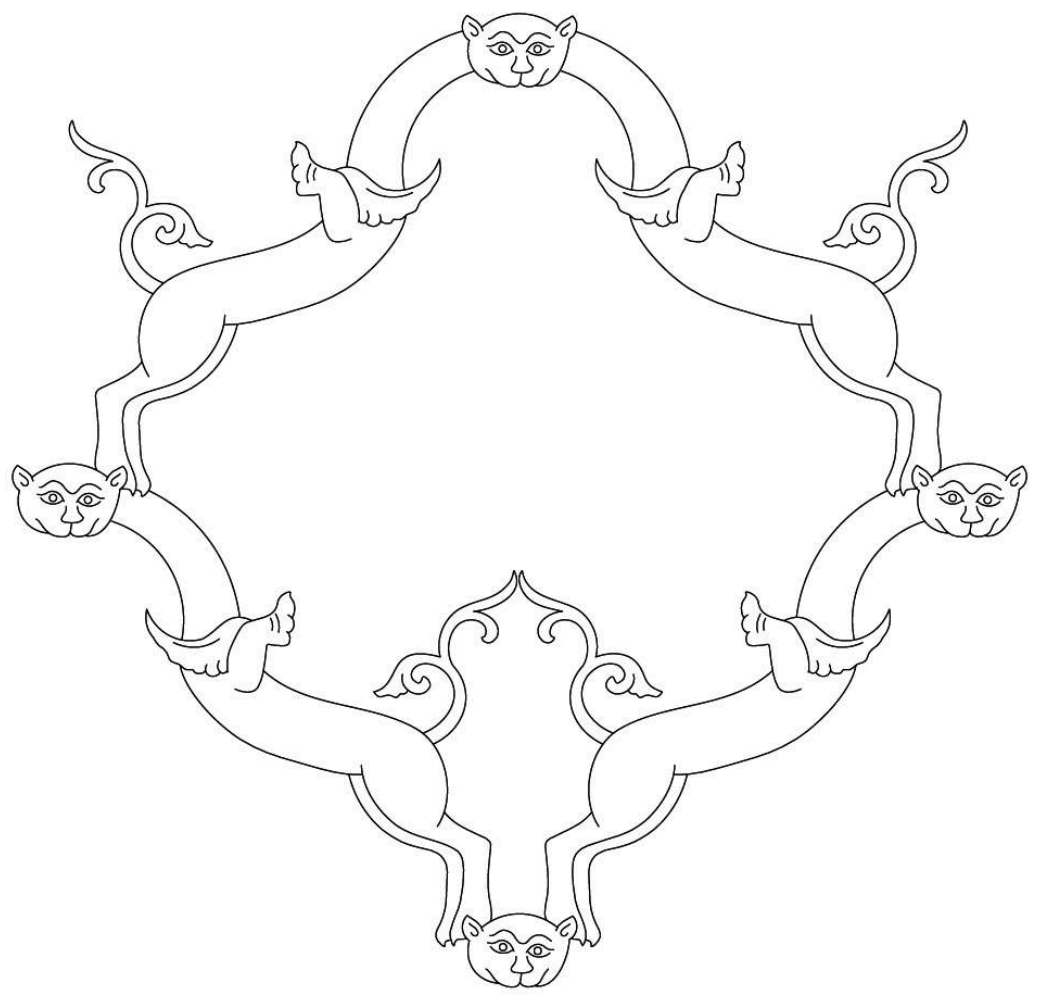

Courtesy of Gerald Kozicz

Fig. 17. Mural in Dunkar caves of Ngari (Western Tibet), ca. late $11^{\text {th }}-12^{\text {th }}$ century, depicting two elephant bodies sharing a head

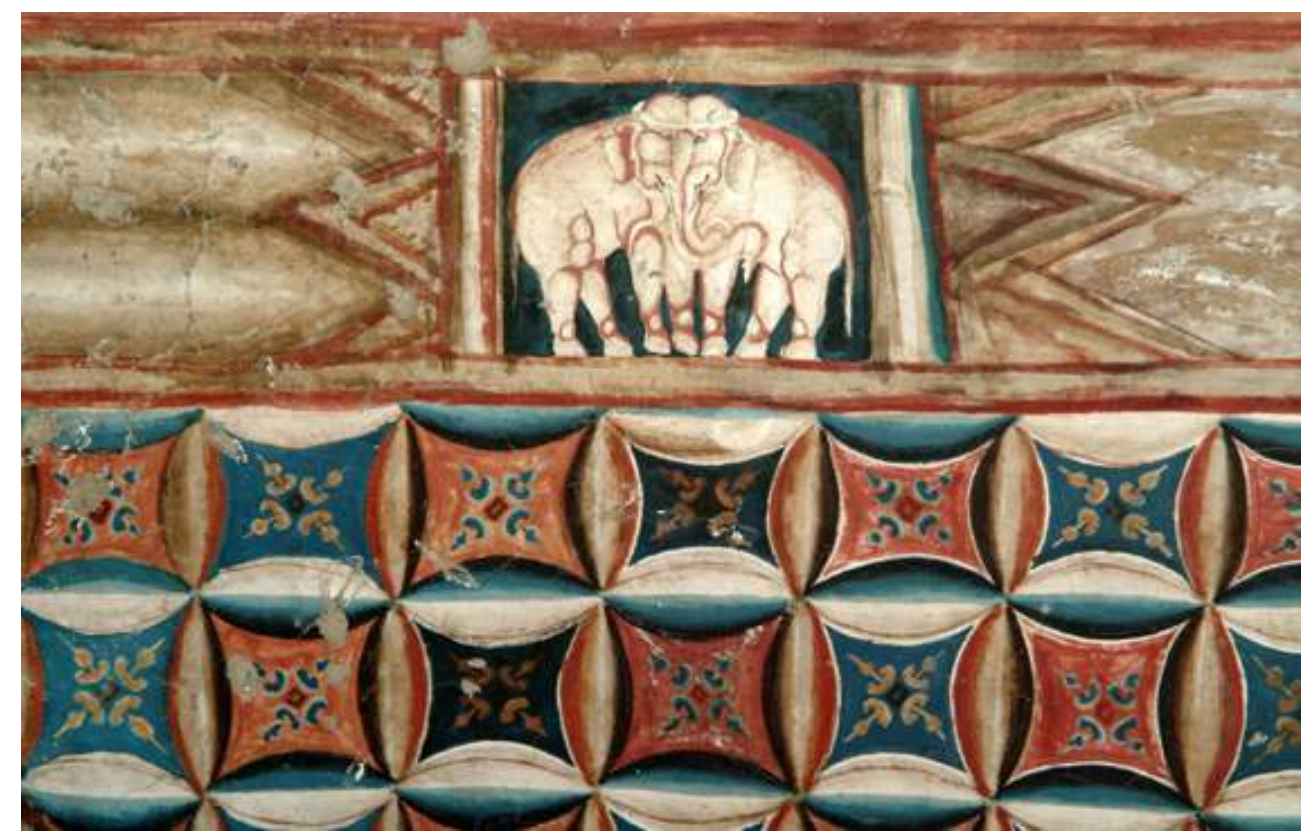

Photo: Rob Linrothe

5 The representational scenes are all contained within this ornamental framing device that emulates the repeat of a textile pattern. Christian Luczanits, who has studied the 
motifs, concludes that, "[a]lthough the scenes are unidentified, it is clear that their main subject is the pious activity of religious adepts: teaching scenes and representations of monks and priests abound." It is now possible to identify several of these scenes more precisely. Along the central area between the bodhisattvas' thighs there are several contiguous scenes that depict episodes in the narrative known as the Starving Tigress (Vyāghrī) or the Mahāsattva jātaka. ${ }^{9}$ The most easily identifiable is at the top right of the sequence (three lozenges down from the dark red garland below the waist in fig. 14) where a striped tigerlike animal stands on a human figure as if devouring him (fig. 18). In the lozenge below and to the viewer's left, however, is an earlier episode in the narrative depicting a standing white-robed man with long hair draping one shoulder and a cloth tied around his forehead (figs. 19 upper, 20). He looks to his left, at a striped tigress who, in accord with the Starving Tigress narrative, growls at her tiny striped and spotted newly whelped cubs lying within an adjacent lozenge (visible in fig. 19, center right). In Ārya Śūra's Jātakamāa $\bar{a}$, a text that begins with the Starving Tigress jātaka (apparently because it was the favorite of the compiler's teacher), the son of a righteous Brahmin family decided to offer himself to the tigress in order to prevent her from committing the karmically devastating act of eating her own cubs. ${ }^{10}$

Fig. 18. Vyāghrī jātaka

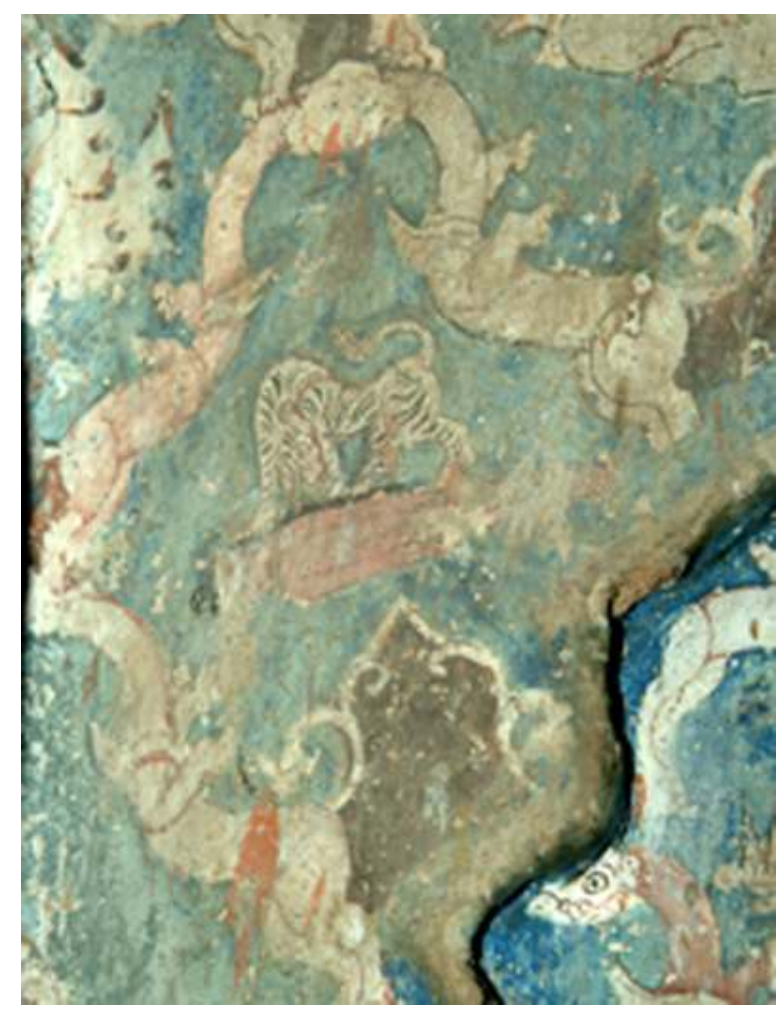

Scene of the tigress devouring the bodhisattva on the Maitreya sculpture dhoti Photo: Rob Linrothe 
Fig. 19. Several scenes from the Vyāghrī jātaka including bodhisattva standing in front of tigress looking at her cubs (above), and cubs (upper right) on the Maitreya sculpture dhotī

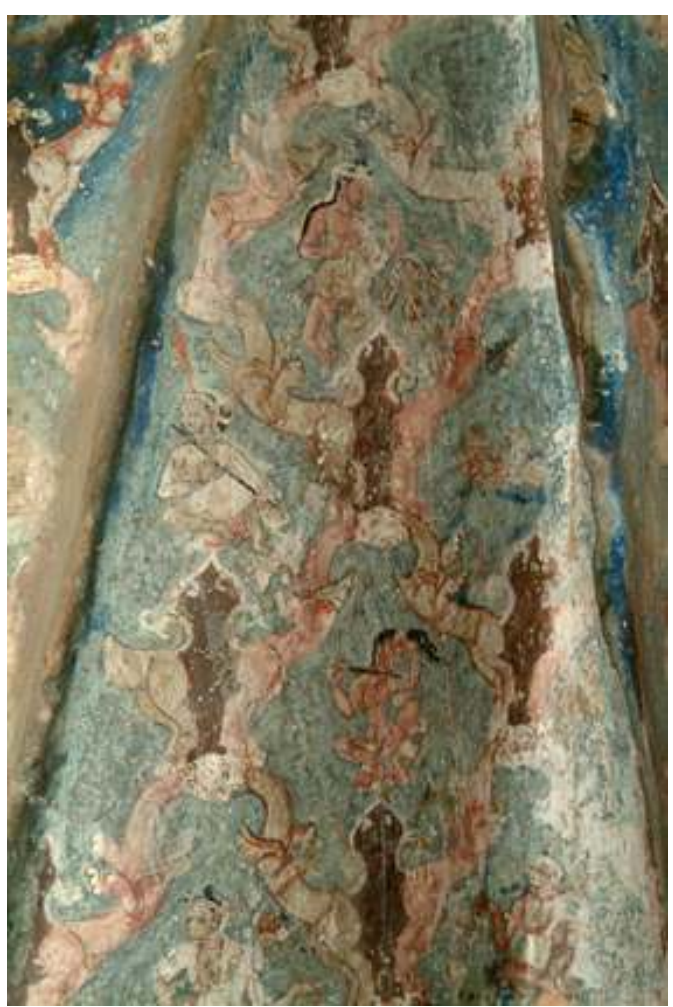

Photo: Rob Linrothe 
Fig. 20. Vyāghrī jātaka

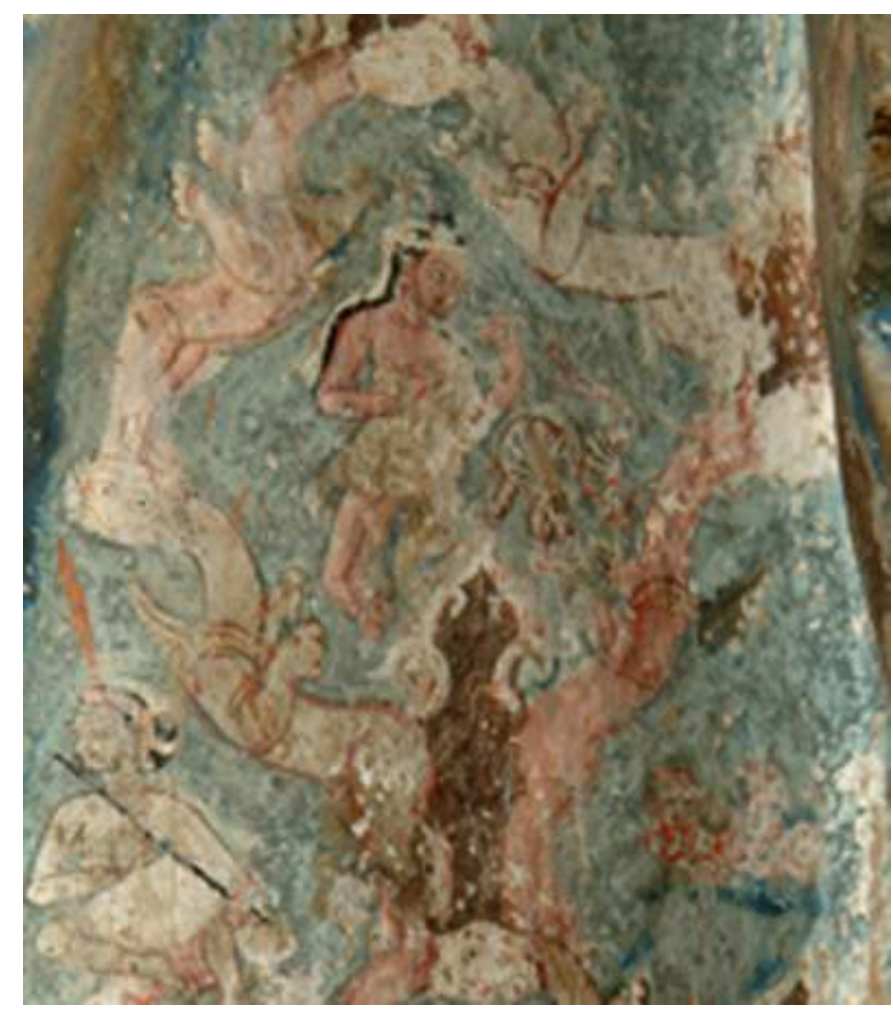

Bodhisattva standing in front of tigress looking at her cubs on the Maitreya sculpture dhotī

Photo: Rob Linrothe

6 The next episode is directly below the standing figure (fig. 20). It depicts the longhaired bodhisattva grasping his now-released hair in a fist at his forehead, while he draws a black stick against his throat (figs. 19 lower center, 21 ). ${ }^{11}$ This is, apparently, a scene of auto-decapitation, or self-sacrifice, a prominent but under-studied category in Indian religion, literature, and art that was known to the Kaśmiri artists. One such scene is on a contemporary 12th-century viragal, or "hero stone" pillar, next to the Hoysaleśvara temple in Karnataka (fig. 22). Like the Mangyu figure, he holds onto his long hair with one hand while putting his sword against his neck. The subject has been identified as a member of the honor-guard of the ruler Ballala II, who decapitates himself after the death of the ruler. ${ }^{12}$ The inclusion of such a scene in the contexts of the Vyāghri jātaka might seem surprising, since in some well-known depictions of the Vyaghri jātaka, ${ }^{13}$ the bodhisattva sacrifices himself by throwing himself off a precipice. In fact that scene also occurs at Mangyu, above and to the left of the tigress trampling and eating the bodhisattva (fig. 23 center, 24 ). ${ }^{14}$ The self-sacrificing bodhisattva is shown upside down, his long hair hanging down, falling from two peaks. 
Fig. 21. Vyāghrī jātaka

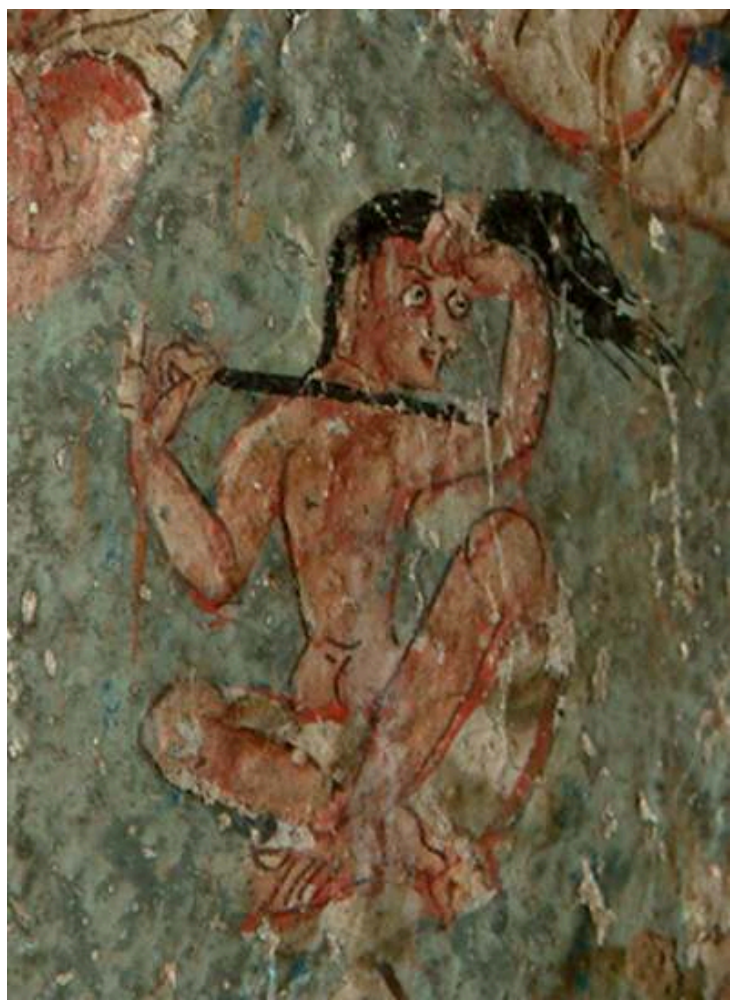

The bodhisattva cutting his throat on the Maitreya sculpture dhoti Photo: Rob Linrothe

Fig. 22. Carving on viragal, or "hero stone" pillar, next to the Hoyśaleśvara temple in Karnataka, $12^{\text {th }}$ century

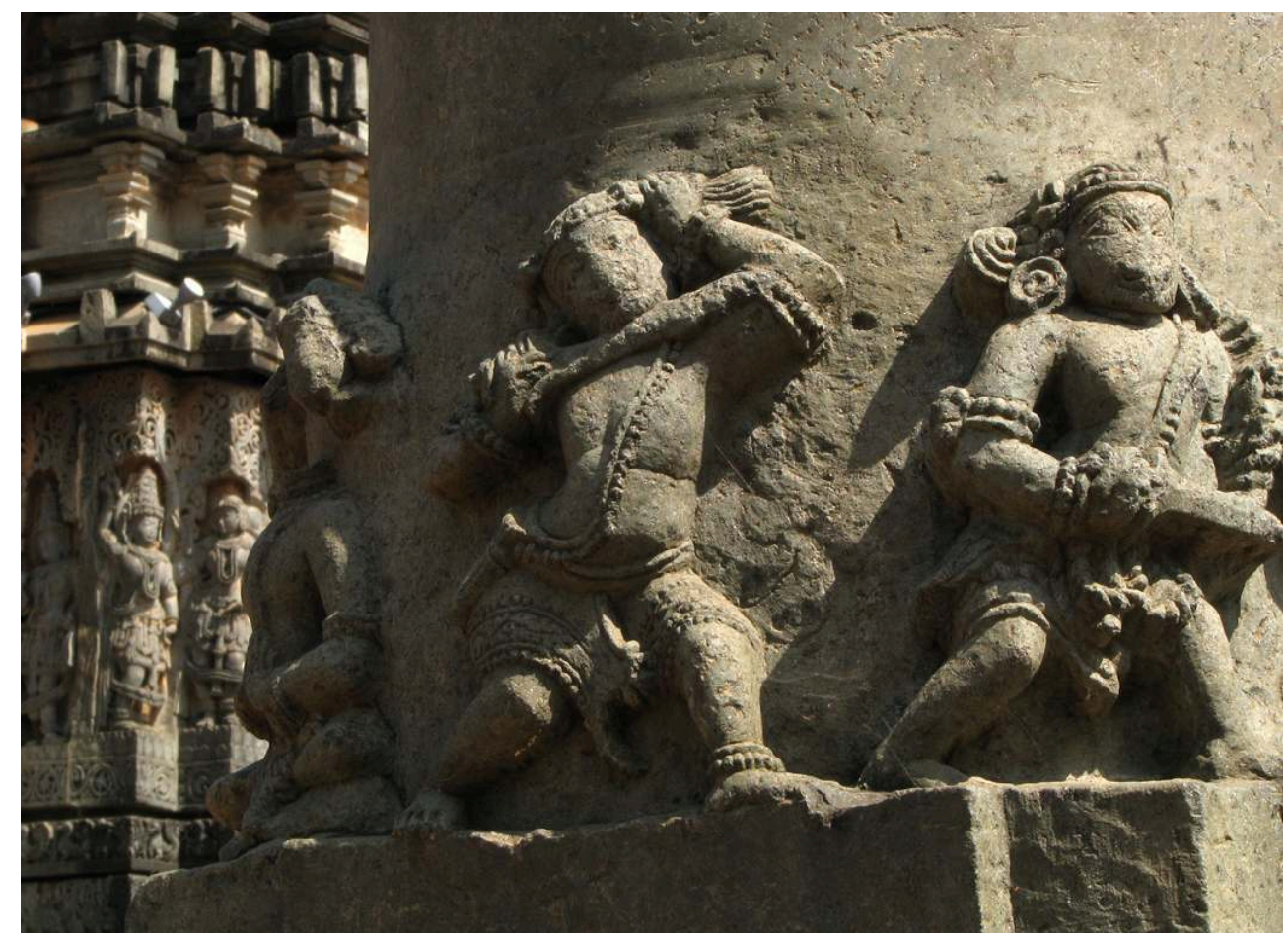

Photo: Rob Linrothe 
Fig. 23. Vyāghrī jātaka

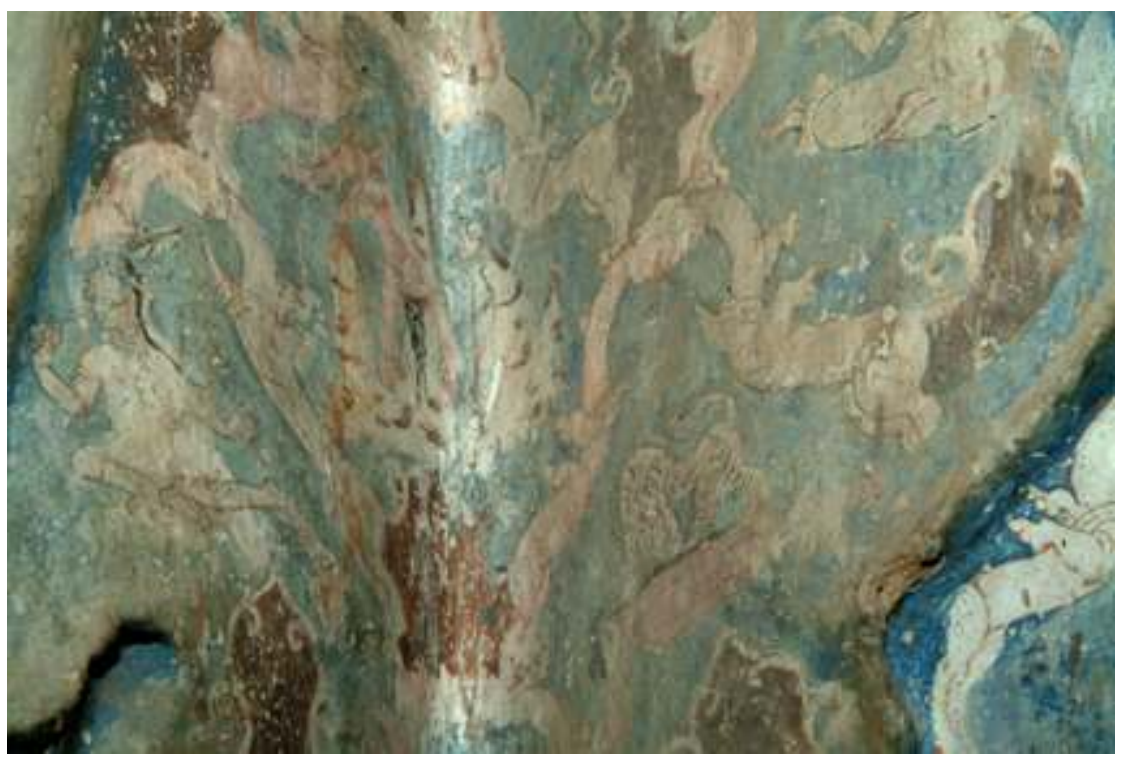

On the left, the bodhisattva casting himself off a cliff; on the right, the tigress devouring him; on the Maitreya sculpture dhoti

Photo: Rob Linrothe

Fig. 24. Detail of Fig. 23, the bodhisattva throws himself from the mountain

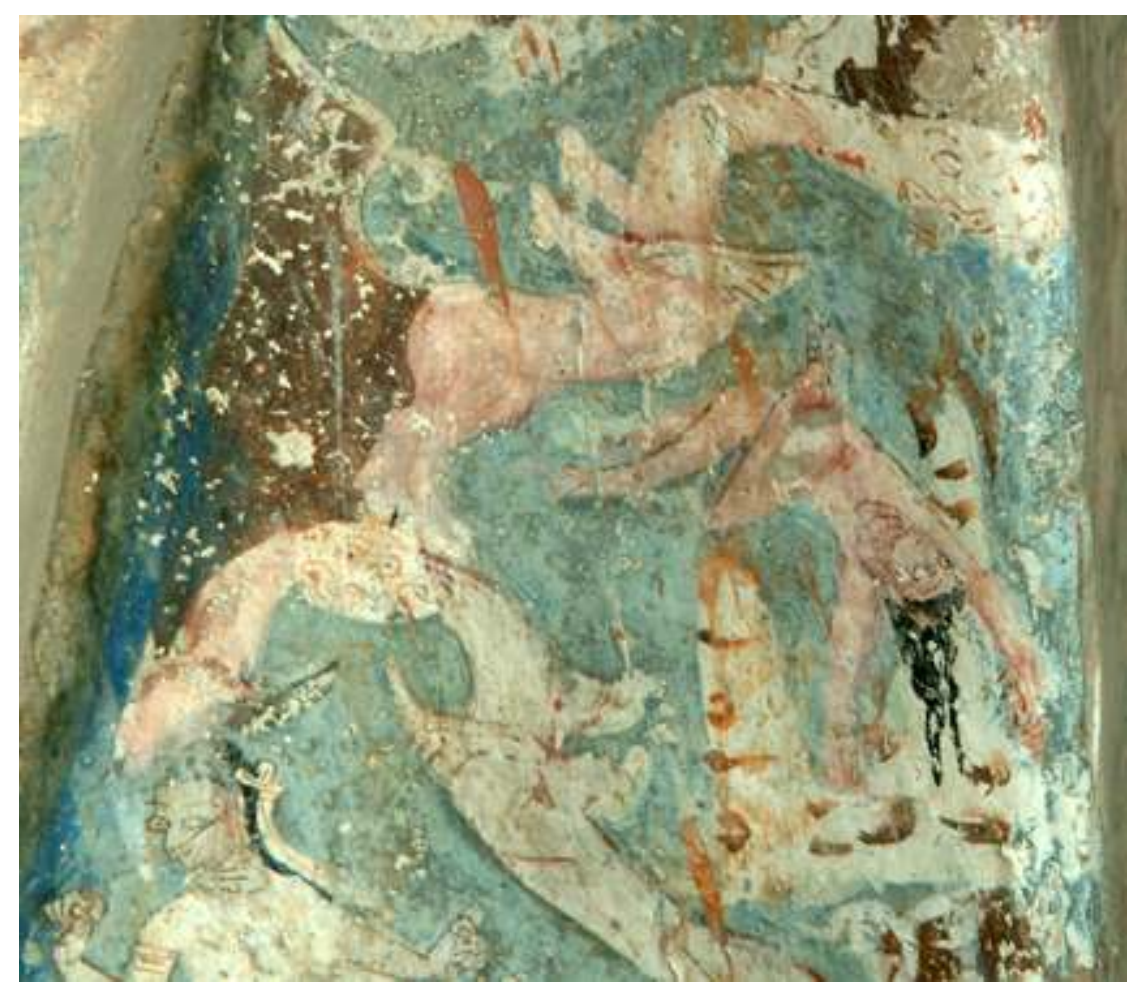

On the Maitreya sculpture dhotī

Photo: Rob Linrothe

7 But what of the attempt at auto-decapitation ? There is no reference to such an action in Ārya Śūra's version of the tale. However, it is part of the jātaka related in the 
penultimate chapter of the Sütra of Golden Light (Suvarnabhāsottama Sütra; hereafter, SS). ${ }^{15}$ Prince Mahāsattva strolls with his brothers (in the Ārya Śūra version, a single disciple attends the bodhisattva) into the great Dvādaśavanagulma forest. They encounter the weakened tigress that had given birth to five cubs seven days earlier. The prince sends his brothers away and lies down before her, but the tigress is too exhausted to eat him. $\mathrm{He}$ "rose up and looked for a knife. The merciful-minded one nowhere found a knife. Taking hold of a very strong bamboo-stick, a hundred years old, and with it cutting open his throat, he fell down before the tigress." The tigress, "seeing the Bodhisattva, whose body was smeared with blood, in a mere flash left only the bones." 16

8 Scenes from the story so far have included, in their narrative order, the bodhisattva's encounter with the tigress who threatens her cubs (fig. 20), the bodhisattva's attempt to auto-decapitate (fig. 21), the flinging of his body from the cliff (fig. 24), and its devouring (fig. 18). In both textual versions of the story, the remains of the body are carried off for reverencing by the prince's disciples, brothers, or the gods. ${ }^{17}$ This scene too is found at Mangyu, in the lozenge to the lower left of the scene of the selfdecapitation (fig. 19). A figure in the conventional posture suggesting flight (knees bent behind and to the side) bears away the severed head with its hair streaming down (fig. 25). The contiguous set of five scenes thus encapsulates the entire Starving Tigress jätaka, indeed, giving two variants of it. It is possible that other adjacent scenes, for example, of single figures watching in wonder, are also connected to the Vyāghrī jātaka, portraying the bodhisattva's companion(s) who are sent off in search of food for the tigress and return to find the traces of his self-sacrifice. (Because the scenes are arranged vertically on two rounded planes where the left and right thighs of the bodhisattva meet at a sharp angle, it is nearly impossible to depict all the scenes in a single in-focus photograph. Fig. 26 shows three of the scenes together and fig. 23 depicts the other two together.) 
Fig. 25. Vyāghrī jātaka

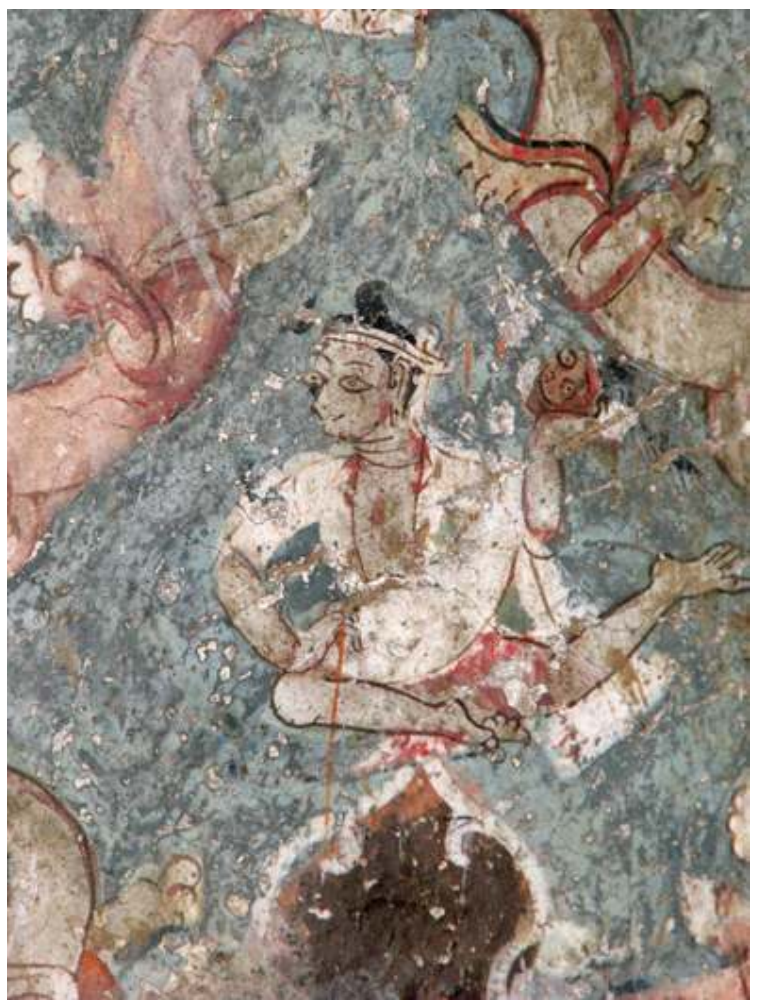

Carrying away of the severed head of the bodhisattva as a relic; on the Maitreya sculpture dhoti Photo: Rob Linrothe 
Fig. 26. View of the dhoti on the inner proper right thigh of Maitreya, showing three of the identified scenes from the Vyāghri jätaka: the bodhisattva's encounter with the tigress who threatens her cubs, the bodhisattva's attempt to auto-decapitate, and the bearing away of the severed head with its hair streaming down

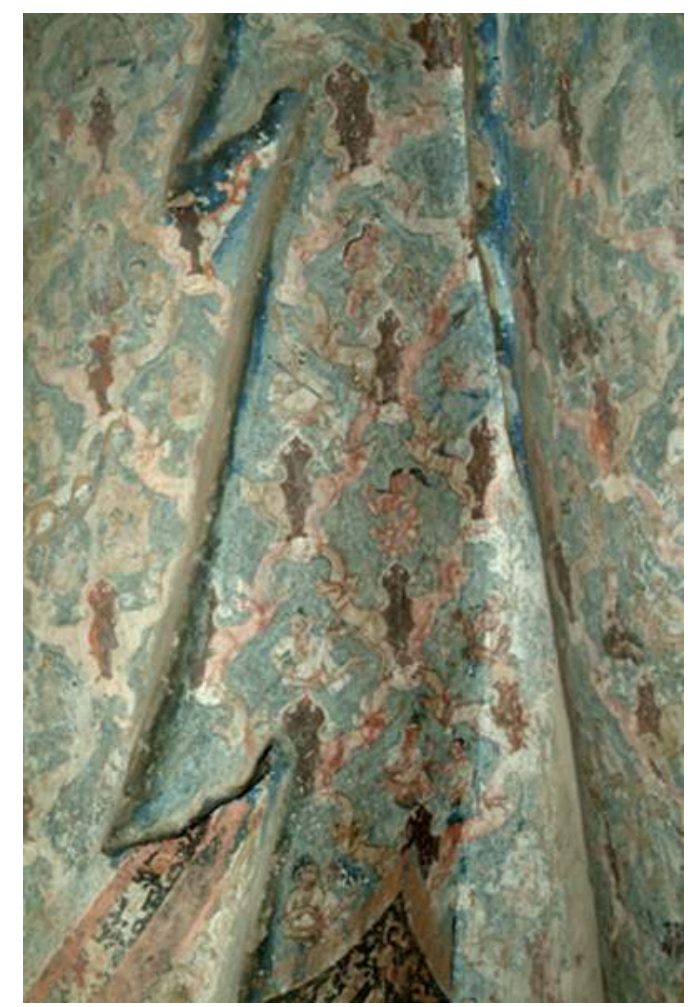

On the Maitreya sculpture dhotī

Photo: Rob Linrothe

9 Other lozenges, not adjacent to the core Vyāghrī scenes, might be connected to the story. For example, there is a sequence on the lower part of the proper left side of the dhoti in which an infant on the lap of a woman, is presented to a priest figure (fig. 27), and in another, a slightly older child stands respectfully between a pandit and possibly his father to receive teachings (fig. 28). These closely mirror both Ārya śūra's textual version of the birth of the bodhisattva into a Brahmin family, his purification through sacraments, and his subsequent education, as well as to the sculptural version of the jātaka as found in Borobudur, where two of the four panels devoted to it depict the child's purification while in his mother's lap and his youthful education by Brahmins. ${ }^{18}$ 
Fig. 27. Woman with an infant on her lap before a monk or priest on the Maitreya sculpture dhoti

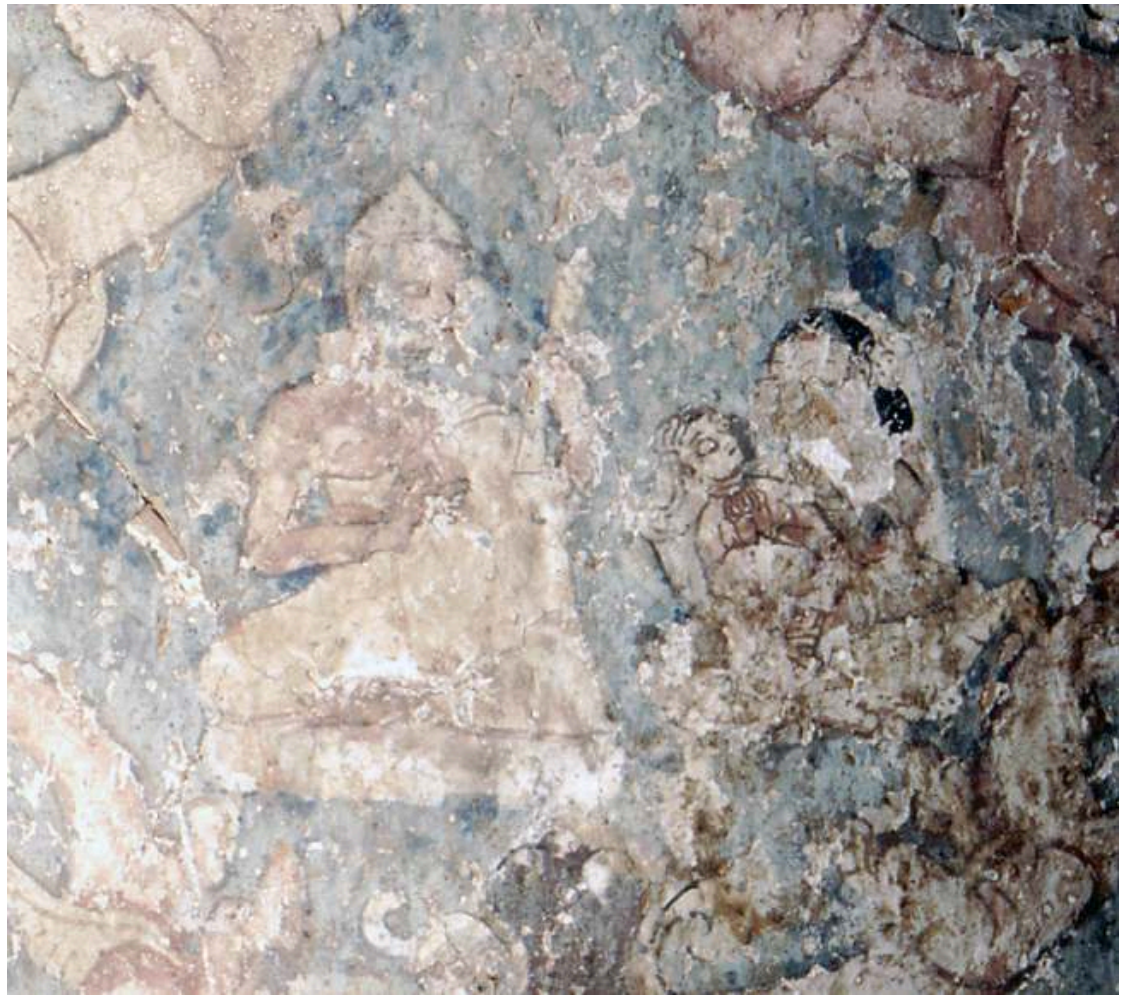

Photo: Peter van Ham

Fig. 28. Father (?) presenting his young son to a monk in a paṇdit's hat on the Maitreya sculpture dhotī

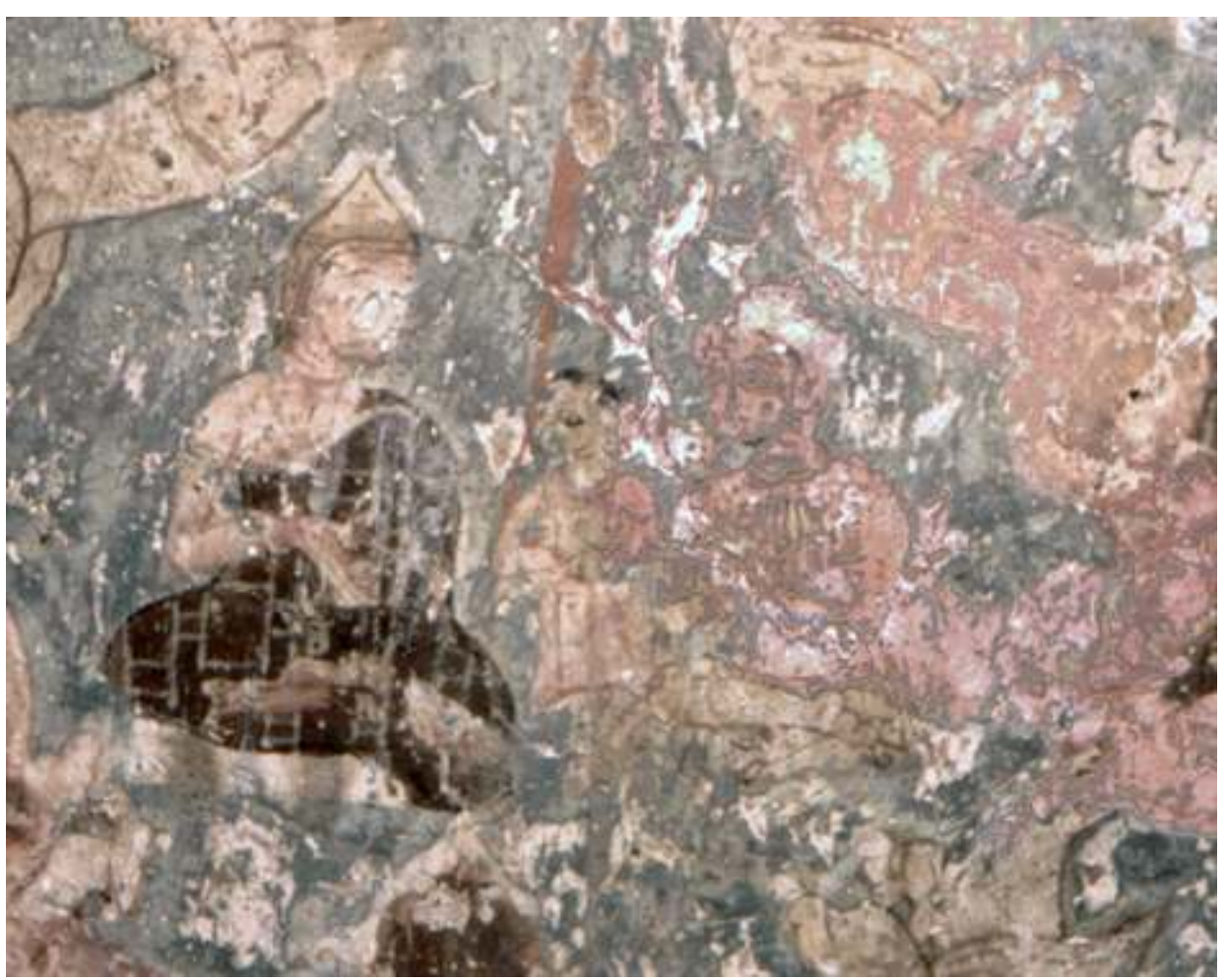

Photo: Peter van Ham 
The same jātaka appears painted on the main wall in the principal shrine at Sumda Chung, on the dhotī of Mahāvairocana, the central sculpture of an implicit or unpacked thirty-seven-deity sculptural Vajradhātu maṇdala (fig. 29). ${ }^{19}$ The upper roundel between the legs of the seated Mahāvairocana depicts a tiger standing on, and presumably consuming, a prostrate human figure, while in the roundel below, the tigress is shown with the smaller cubs which attentively face her (fig. 30). Just as the episodes of the Buddha's life on the dhoti of Maitreya in the Alchi Sumtsek point to the important fact of Maitreya's reenactment of the stages of Sākyamuni's becoming Buddha, ${ }^{20}$ so too at Sumda Chung, the appearance of Saakyamuni's prior incarnation as the compassionate Mahāsattva elucidates the ultimate identity of Mahāvairocana and Śākyamuni. Their two moments of apotheosis, whereby Siddhartha becomes Buddha, and Buddha becomes Mahāvairocana, are referenced here: the enlightenment at Vajrāsana, and the "diadem initiation" in Akaniștha heaven, respectively. ${ }^{21}$ The diadem initiation is explicitly depicted at Sumda Chung, with devas lowering a crown on Mahavairocana's four-fold heads (visible in fig. 29), while the enlightenment moment is implied by the very presence of the jātakas, which, as the Nidānakathō indicates, warrants the enlightenment. ${ }^{22}$ At Alchi, Sumda, and Mangyu, then, motifs on the dhotis play roles that are iconographic and theological.

Fig. 29. Mahāvairocana, central sculpture of a thirty-seven-deity sculptural Vajradhātu maṇdala on the main wall in the principal shrine at Sumda Chung, ca. $12^{\text {th }}$ century

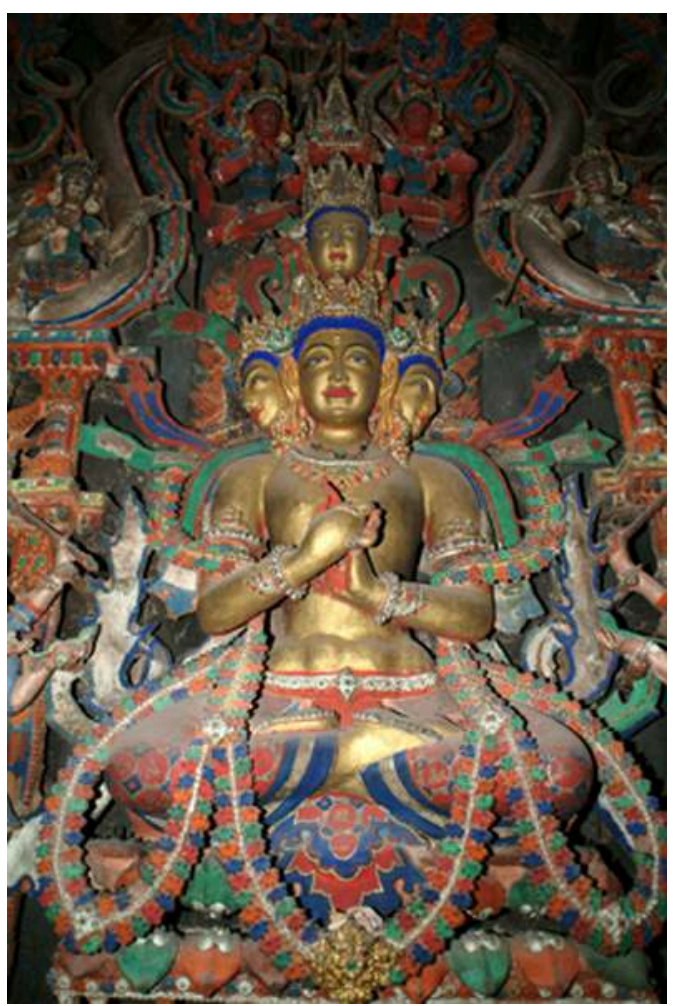

Photo: Rob Linrothe (after cleaning, 2009) 
Fig. 30. Detail of fig. 29

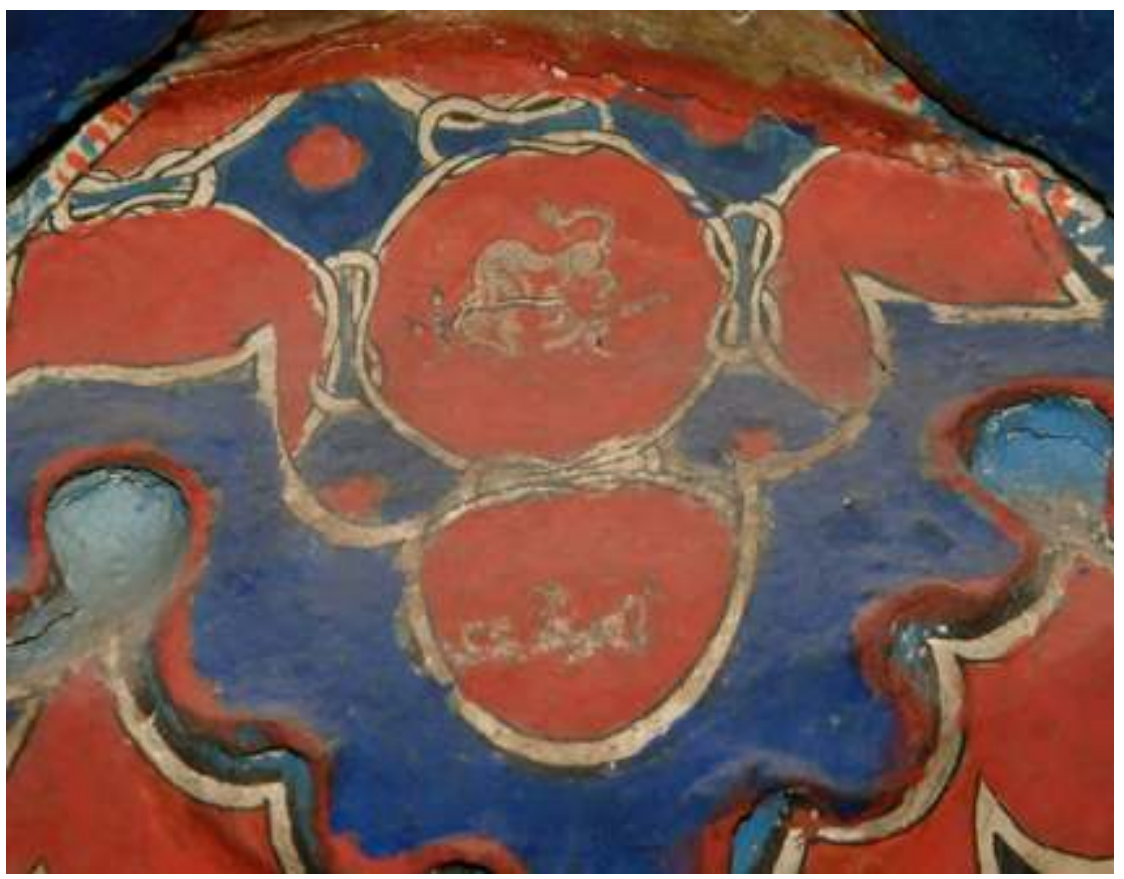

Two scenes of the Vyāghrī jātaka

Photo: Rob Linrothe (after cleaning, 2009)

Returning to Mangyu, none of the other scenes on the dhoti can be clustered under so unambiguous an interpretation as the Starving Tigress narrative. However, another group resembles the pilgrimage of Sudhana as related in the GS, in which he visits a series of fifty-three teachers, including all three of the bodhisattvas depicted on the walls of Mangyu tower: Mañjuśrī, Maitreya, and Avalokiteśvara. This extensive scripture is well known from paintings at the main Dukhang of Tabo Monastery in a relatively naïve, local Indo-Tibetan style, ${ }^{23}$ in the Lhasa Jokhang in a Newar mode,${ }^{24}$ in eastern India, ${ }^{25}$ and from 9th-century sculpture in Central Java at Borobudur. ${ }^{26}$ The story would certainly have been known in Kaśmīr as well. In fact, some of the same Kaśmīi translators who worked on the SS also translated the GS. ${ }^{27}$ The teachers Sudhana visits are a heterogeneous group, including monks, nuns, laymen and -women, "night goddesses," and bodhisattvas. At least four scenes on the Mangyu dhoti depict a youth with a ponytail (often a marker of youthfulness), alone (fig. 31) or in attendance on a layman (fig. 32), a female figure (fig. 33), and a monk (fig. 34). Each of these could be understood as a scene from Sudhana's travels to or visits with one of his teachers. Other candidates for this interpretation are damaged so that the ponytail cannot be identified (ex. fig. 35). In some cases the ponytail is absent, but the scene includes a younger, smaller figure in attendance upon a larger teacher, lay or monastic (fig. 36, upper and lower). Most of these are clustered in the same area as the vignettes in which the ponytail is clear. There are also depictions of monks and a young man offering worship, seated or standing beside Kaśmīri-style stūpas with multi-stepped platforms, small andas, tall spires, and hanging banners (figs. 37-38). ${ }^{28}$ One scene shows two figures offering reverence to a standing Buddha figure with a halo (fig. 39). These too recall episodes in the GS and relate to carved reliefs at Borobudur and, especially, eastern Indian manuscript illustrations of the GS. ${ }^{29}$ Interestingly, the Borobudur sculptures of the GS include a scene in which Sudhana rides a palanquin right after the visit to 
Jayottama, the twenty-fifth master. A comparable scene is found on the dhoti at Mangyu (fig. 40). ${ }^{30}$ However, no mention of a litter occurs in that or the subsequent section of the text.

Fig. 31. Youthful figure (Sudhana ?) with a ponytail on the Maitreya sculpture dhotī

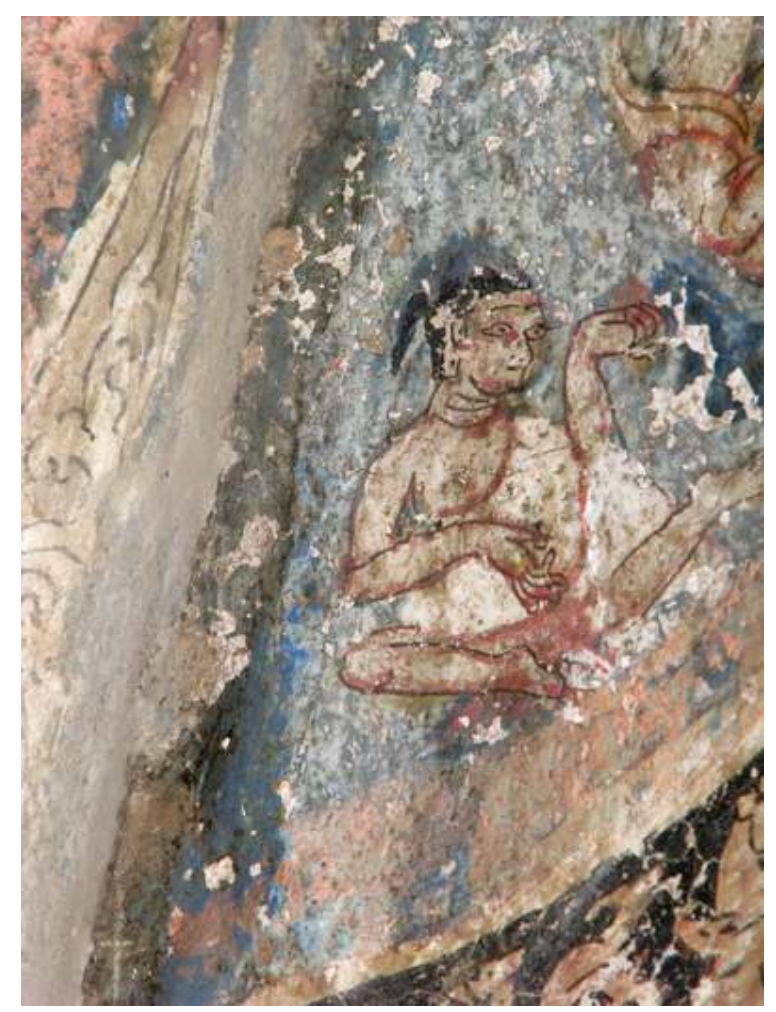

Photo: Rob Linrothe

Fig. 32. Youthful figure (Sudhana ?) with a ponytail attending a layman on the Maitreya sculpture dhotī

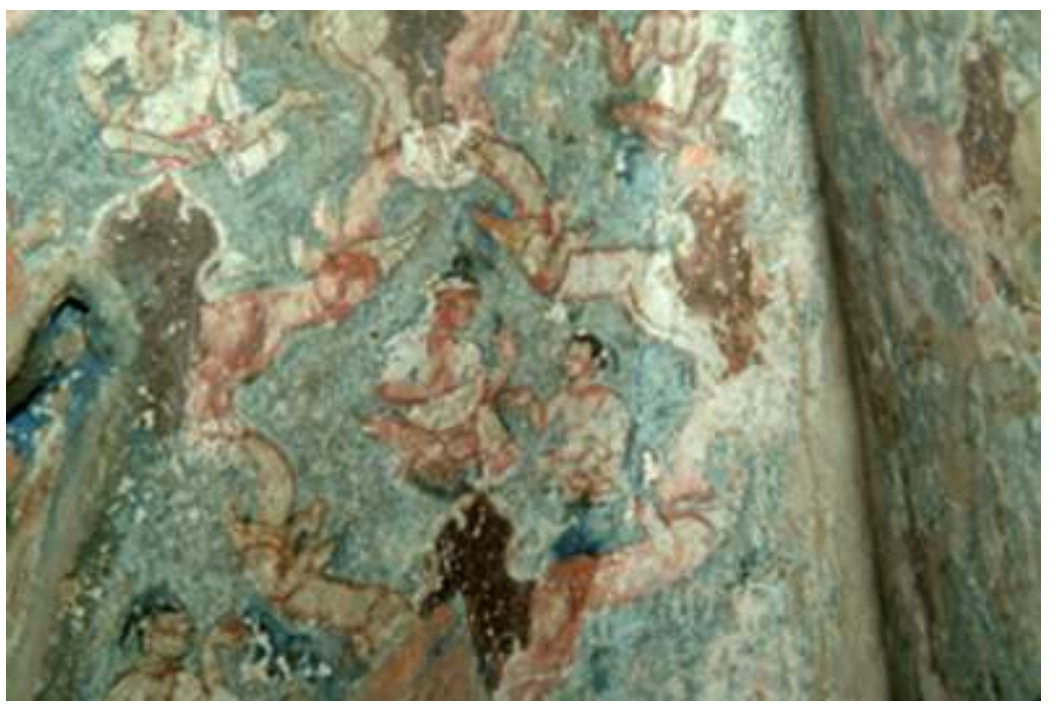

Photo: Rob Linrothe 
Fig. 33. Youthful figure (Sudhana ?) with a ponytail attending a laywoman on the Maitreya sculpture dhotī

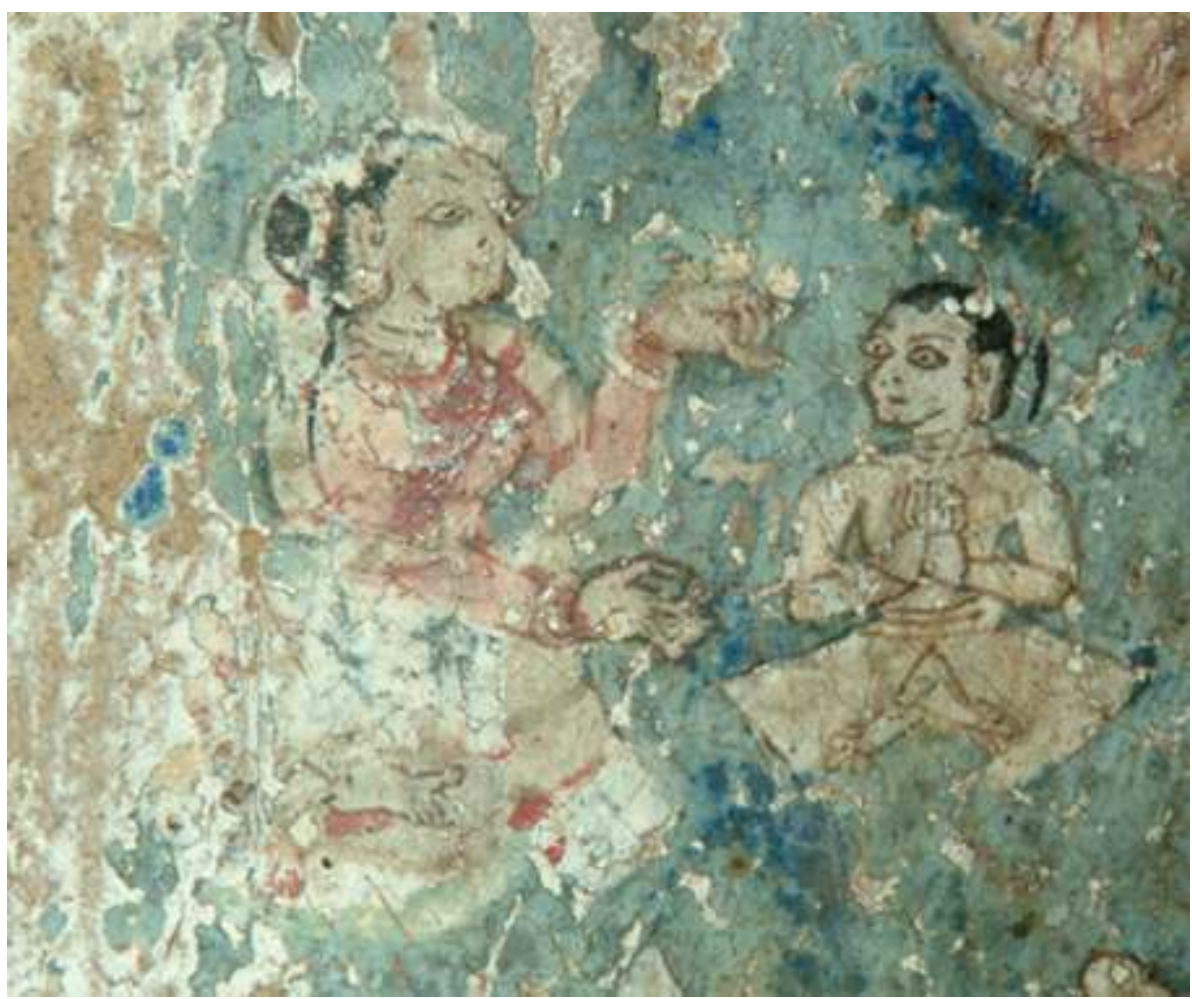

Photo: Rob Linrothe

Fig. 34. Youthful figure (Sudhana ?) attending a monk on the Maitreya sculpture dhotī

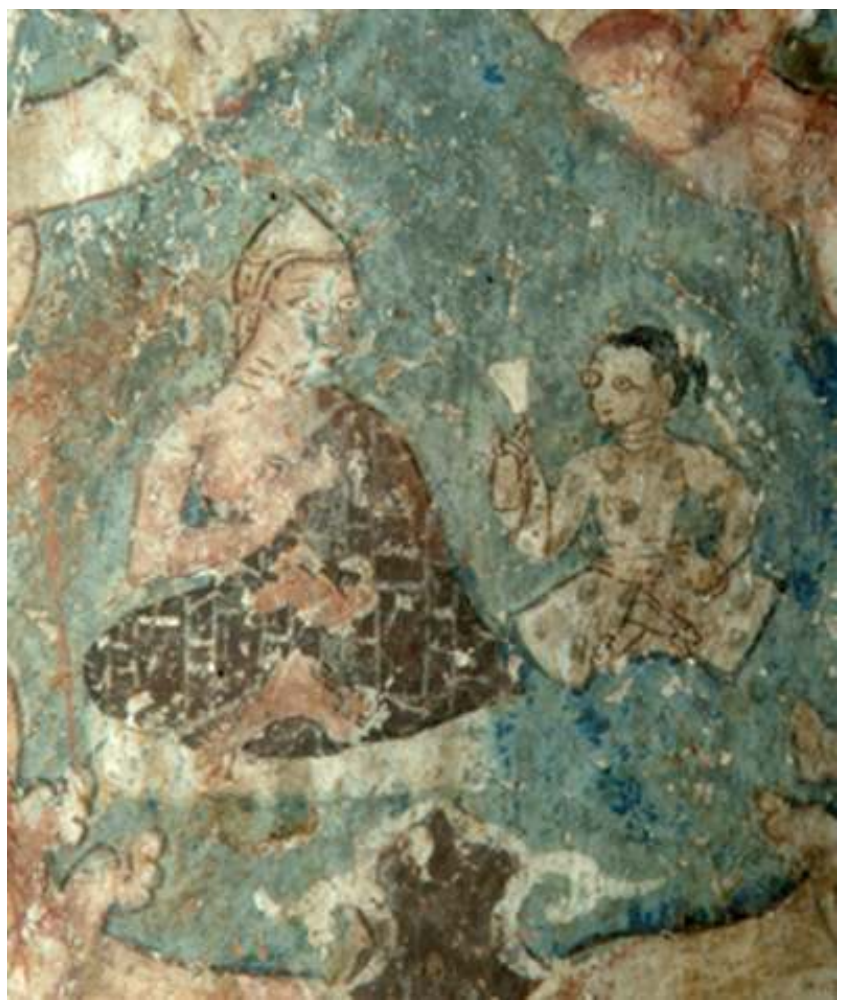

Photo: Rob Linrothe

Études mongoles et sibériennes, centrasiatiques et tibétaines, 42 | 2011 
Fig. 35. Youthful figure (Sudhana ?) attending a monk on the Maitreya sculpture dhotī

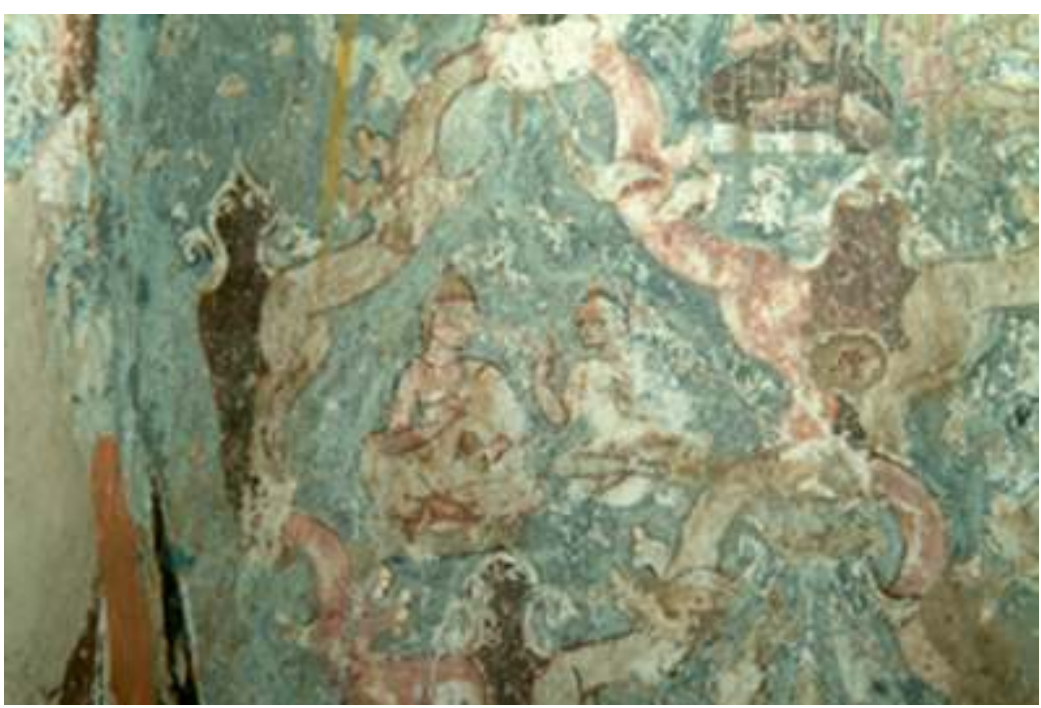

Photo: Rob Linrothe

Fig. 36. Youthful figures (Sudhana ?) attending on a lay religious figure (above) and a monk (below) on the Maitreya sculpture dhotī

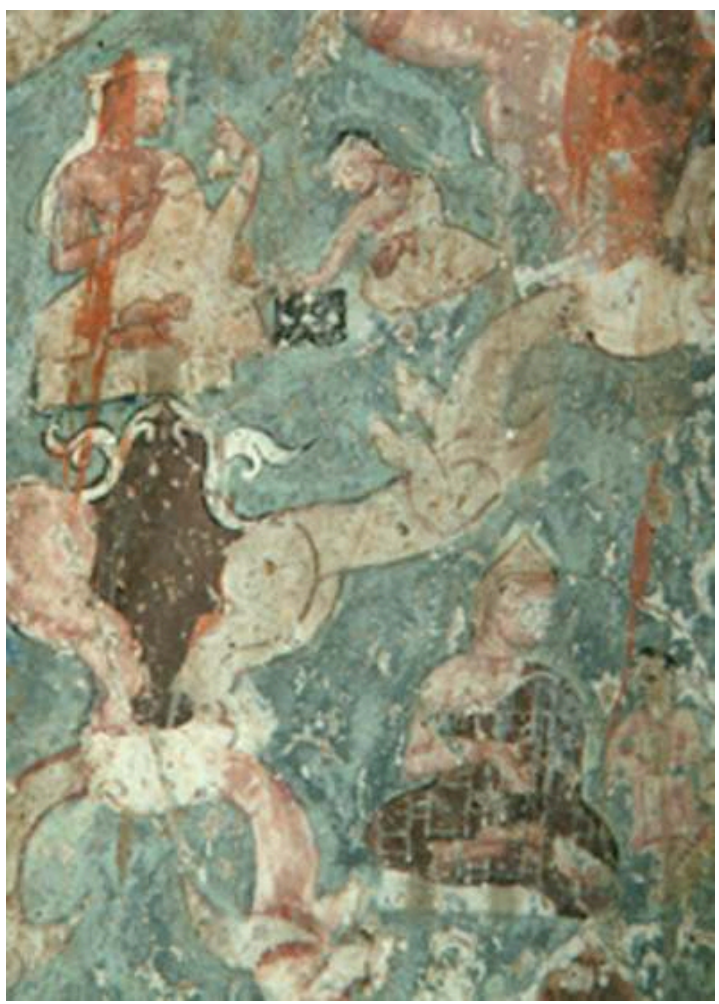

Photo: Rob Linrothe 
Fig. 37. Seated youthful figure (Sudhana ?) with a monk offering worship to a Kaśmīri-style stūpa on the Maitreya sculpture dhotī

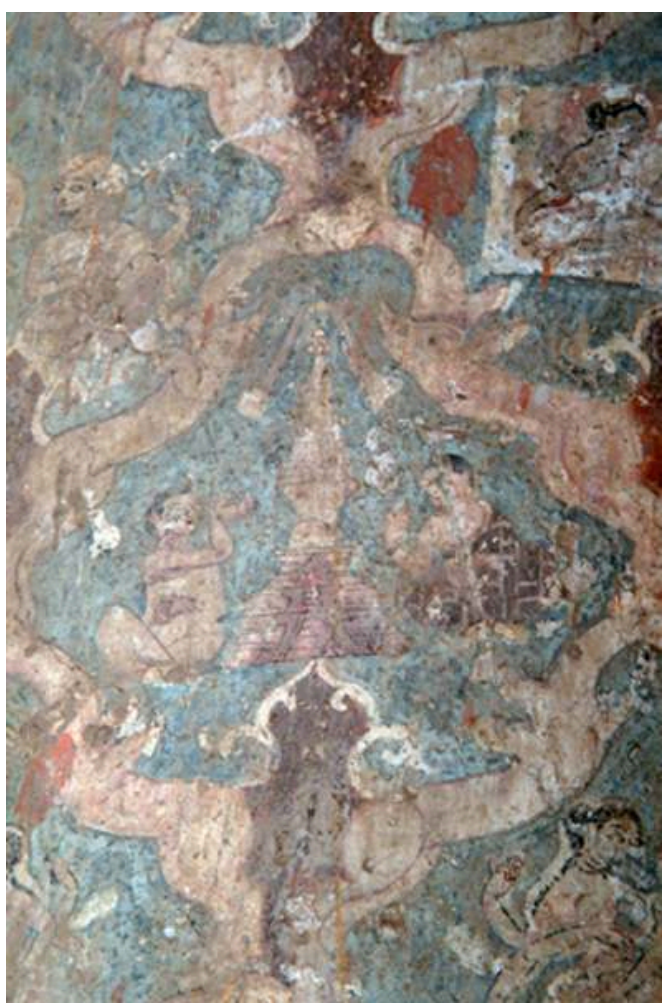

Photo: Rob Linrothe 
Fig. 38. Standing figure (Sudhana ?) with a monk offering worship to a Kaśmīri-style stūpa on the Maitreya sculpture $d_{h o t i ̄}$

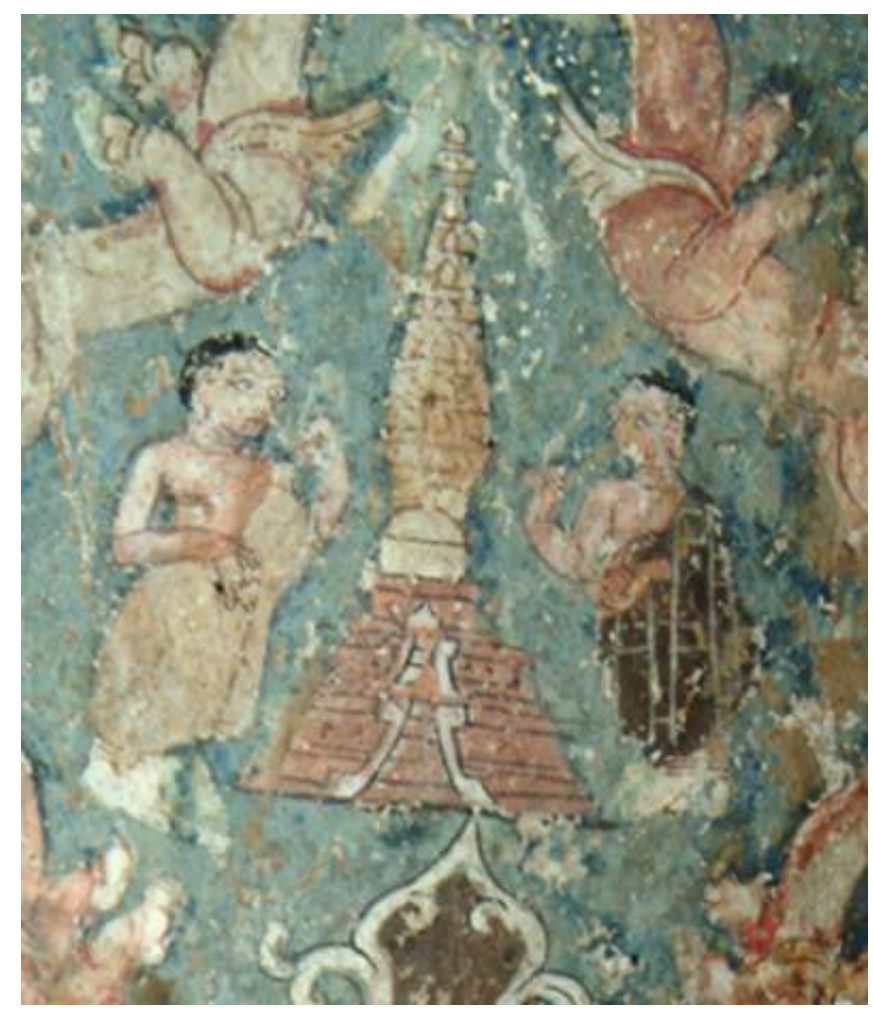

Photo: Rob Linrothe 
Fig. 39. Two figures offering reverence to a standing Buddha (sculpture ?) on the Maitreya sculpture dhotī

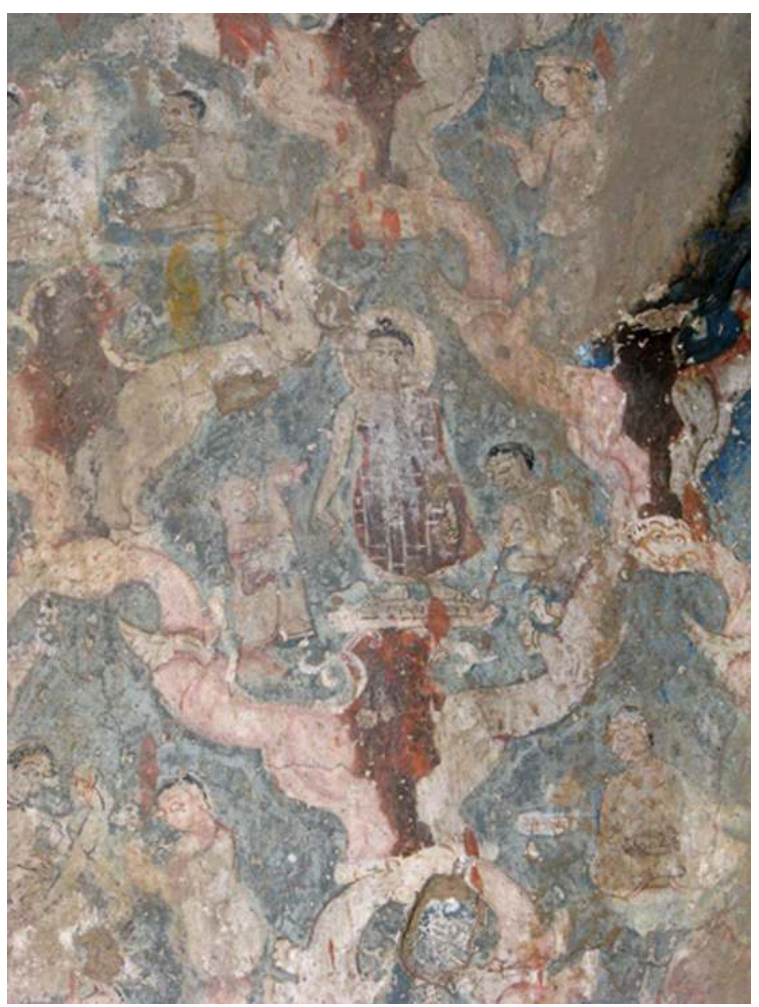

Photo: Rob Linrothe

Fig. 40. Youthful figure (Sudhana ?) being carried on a palanquin on the Maitreya sculpture dhotī

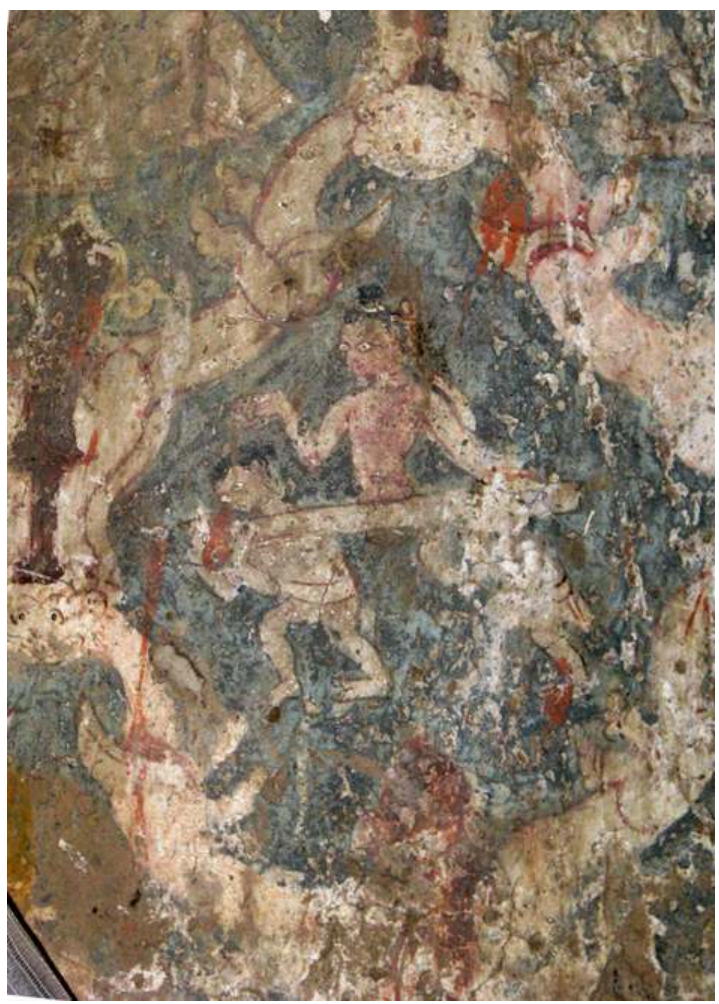

Photo: Rob Linrothe

Études mongoles et sibériennes, centrasiatiques et tibétaines, 42 | 2011 
12 Several lozenges of the Mangyu dhoti feature six-armed female goddesses, sometimes with a smaller worshiper. One is in good condition, revealing details of a short-sleeved tight jacket of red cloth and an elaborately upswept bun at the back of her head, partially covered with a long white veil (figs. 41-42). ${ }^{31}$ These figures resemble Prajñāpārāmitā, but without the visible presence of her attribute, a book, they cannot be firmly identified as such. They might be understood, however, as the nightgoddesses Sudhana visits in the GS. Although known depictions of the night-goddesses have only two arms, their descriptions in the text are vague other than noting their beauty. ${ }^{32}$ A quality that is textually associated with both Prajñāpārāmitā and the nightgoddesses is wisdom, a shared characteristic which might have led to a conflation of goddess imagery, just as Tārā and Prajñāpārāmitā are intertwined in Western Tibet. ${ }^{33}$

Fig. 41. Six-armed Prajñāpārāmitā or night goddess on the Maitreya sculpture dhotī

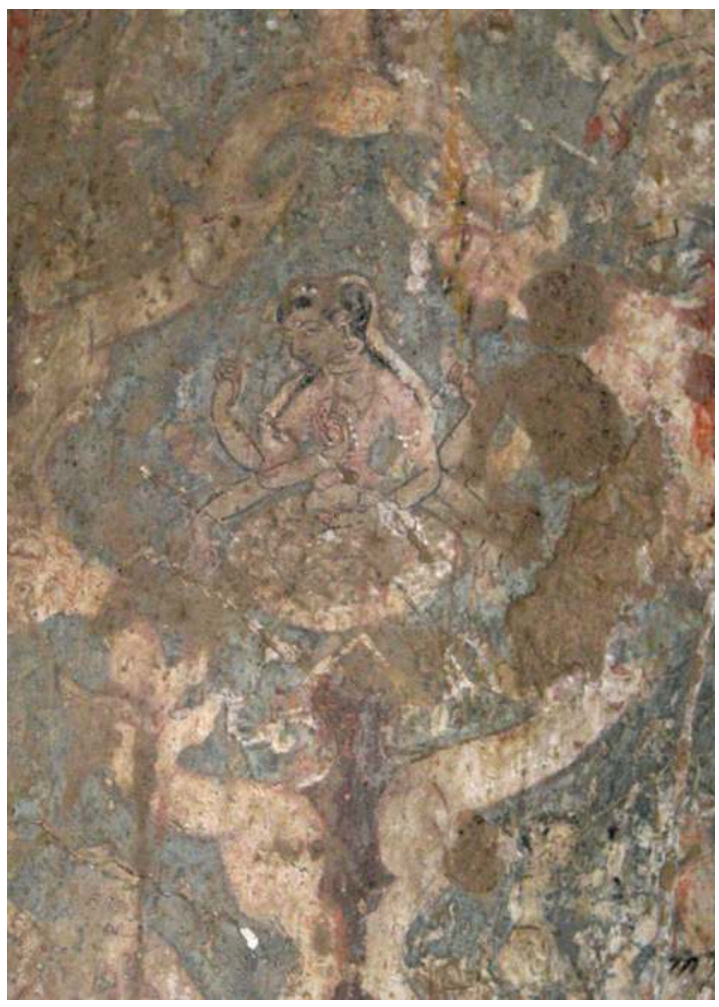

Photo: Rob Linrothe 
Fig. 42. Youthful figure (Sudhana ?) offering reverence to a six-armed Prajñāpārāmitā or night goddess on the Maitreya sculpture dhoti

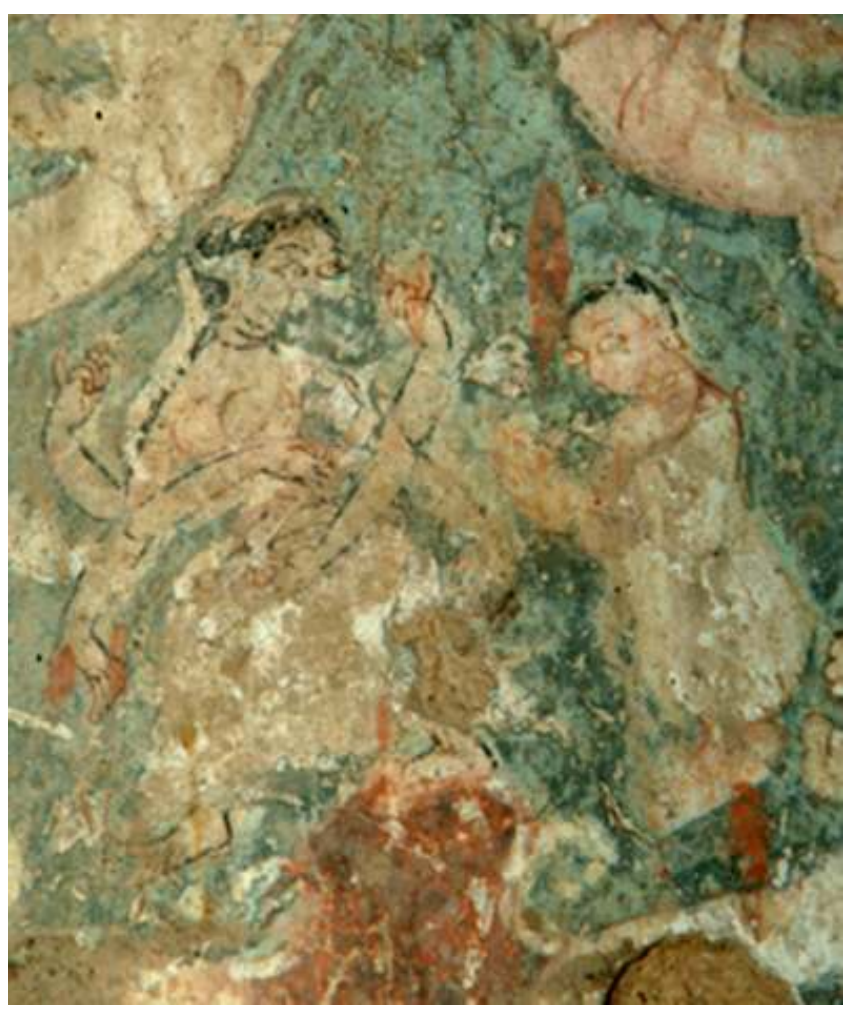

Photo: Rob Linrothe

These are among the more plausible resemblances between the scenes on the Mangyu dhoti in question and the GS narratives; there is no need to present more speculative interpretations. However, one episode in the text may help us understand the structure as a whole. This is one of the longest, climactic chapters of the text, when Sudhana encounters Maitreya. Interestingly, at Tabo, the Maitreya chapter is "the largest panel in the frieze," ${ }^{34}$ while at Borobudur, according to Jan Fontein, "in statistical terms, [the section of the text on Sudhana's visits to Maitreya and Samantabhadra] accounts for fifteen percent of the length of text, but for seventy-two percent of the wall length available for its illustrations on the third and fourth gallery of the monument." ${ }^{35}$ In this long chapter of the text, ${ }^{36}$ Sudhana approaches Maitreya, who leads him to the tower of the adornments of Vairocana (Vairocanavyūhalankkāragarbha kūtāgāra) and encourages him to enter. ${ }^{37}$ Once he steps inside and the door closes behind him, he has mystic visions that center on Maitreya. He sees where Maitreya "first aspired to supreme perfect enlightenment, what his family was... how long he lived, what age he lived in." He sees where Maitreya carried out practice, as a king advocating virtue, as a god, among monks, contemplating and expounding the teachings to various beings. Sudhana sees Maitreya following the stages of the lifestory of Śākyamuni-taking seven steps, living in the palace, becoming enlightened, being asked by Brahma to set the wheel of dharma in motion, and the like. Sudhana hears a voice narrating Maitreya's "so many hundreds of difficult sacrifices in the practice of transcendent giving. ... [T] he enlightening being so-and-so, in search of truth, relinquishes kingship, wealth, family, hands and feet, eyes and head and practices self-mortification by fire ... as a spiritual preacher, giving the gift of religion, [who] performs the service of religion, raises the 
banner of religion ... adorns monuments of the enlightened, has images of buddhas made, comforts beings." ${ }^{38}$ Sudhana sees Maitreya "as a wonder horse, rescuing people on the isle of demons in the ocean ... in another, as a physician, engaged in treating the sick ... listening to spiritual benefactors ... in the form of a Buddhist disciple ... decorating monuments of buddhas, having statues of buddhas made, enjoining people to honor the buddhas." 39

In addition, all these visions are located on a "checkerboard lapis-lazuli surface" (emphasis added, here and below), in which he sees "inconceivable reflections in each square; here he saw the reflection of a land, there the reflection of a Buddha. All the arrays of adornments in those towers he saw reflected in each of the squares. ... [Sudhana] also saw the walls of the palatial towers resplendent with checkerboards of all jewels, and in all the jewel square[s] he saw Maitreya carrying out all the practices of enlightening beings, as he had done while performing enlightening practice in the past: in one square he saw Maitreya giving away his head; in another, giving away clothing... in another giving away his skin; in another, giving away his limbs; in another, giving away his body." 40

On the one hand, these visions have counterparts on the dhotī. Obviously, the Vyāghri jātaka (figs. 18-21, 23-26) fits with Maitreya's recapitulation of the course of Śākyamuni's multitude of self-sacrificing lives, of "giving away" (pradāna) his head and body. The condensed list of what Sudhana sees reads like an inventory of the themes in the lozenges, including a white "wonder horse" (fig. 43), a physician healing a sick man (fig. 44), making images of the Buddha (fig. 39), adorning monuments to the Buddha and the enlightened (figs. 37-38), and preaching to people.

Fig. 43. Figure riding a white ("wonder" ?) horse on the Maitreya sculpture dhotī

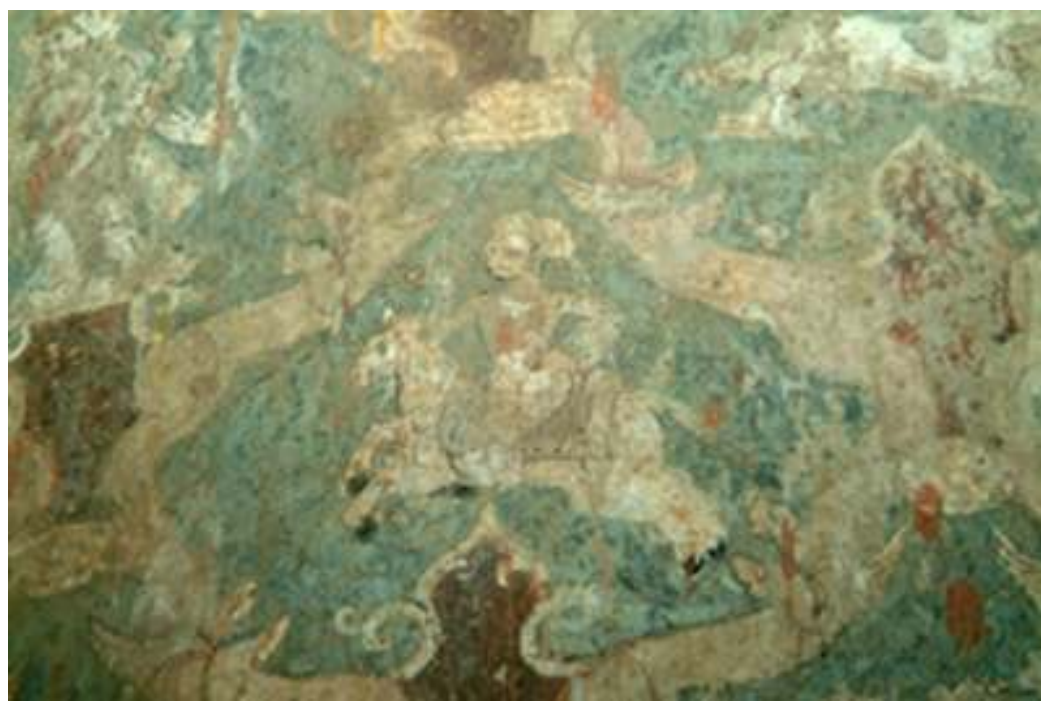

Photo: Rob Linrothe 
Fig. 44. Physician healing a sick man on the Maitreya sculpture dhotī

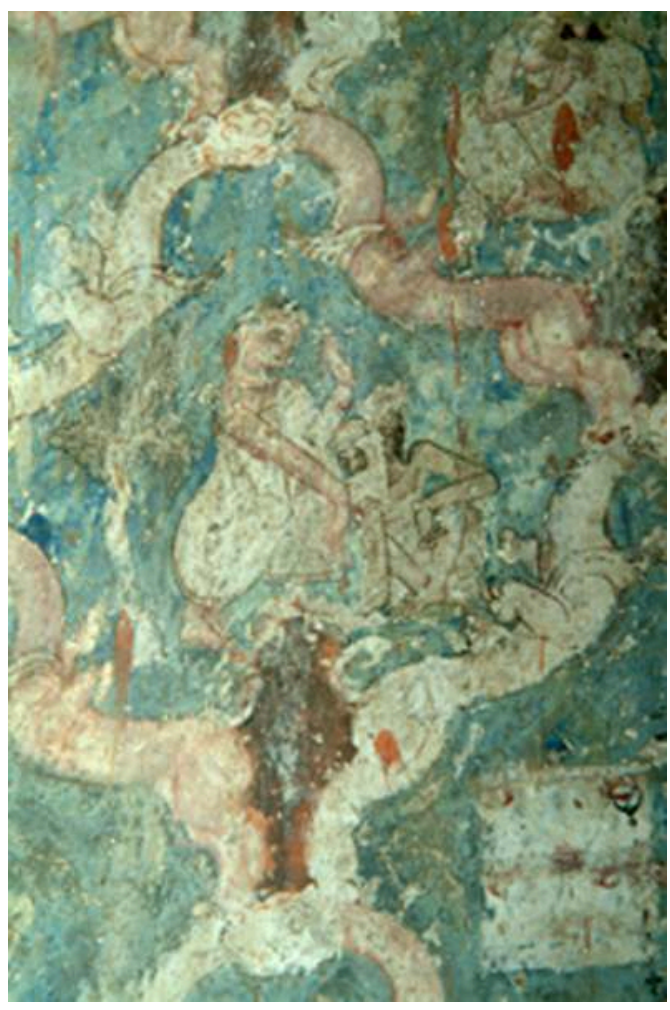

Photo: Rob Linrothe

16 The Vyāghri jātaka's prefigurine presence at Mangyu, placed centrally between the bodhisattva's legs as if to call attention to it, is a recognizable visual synecdoche for the multitude of previous lifetimes devoted to the benefit of sentient beings. It simultaneously works as a reference to Sudhana's visionary experiences under Maitreya's tutelage. Thus, the representational patterns on the sculpture's dhoti reinforce the identification of the main sculpture as Maitreya.

On the other hand, Sudhana is the paradigmatic pilgrim whose actions in entering Maitreya's kūtāgāra (jeweled tower) are precisely mirrored by the living pilgrim entering the eastern tower at Mangyu ${ }^{41}$ Text and image share the protean ambiguity of the dazzling thaumaturgic display that hypnotizes Sudhana by its constant shifts. The textual account and the phenomenological experience are congruent in their flowing indeterminancy. The visual artists have not been slavishly literal and exhibit both inspiration and independence. These are intentional effects, not "errors of understanding" on the part of the artist(s) or ourselves, even at such a remove. ${ }^{42}$ The patterns and scenes on the shimmering painted textile that drapes the sculpted bodhisattva like a second skin, its vibrant "lapis-lazuli" ground identical in color to the walls that surround it, are activated into a visionary screen in which a constellation of fragments enact the Buddhist experience of meaning, of jñāna-darśana in a suitably transient visual language. As David McMahan has argued for the textual rhetoric of the GS, this sensual configuration at Mangyu is not intended to convey "ideas" about the nature of reality but "visions" of it. Such affective visual expressions are operative, through form, through visual rhetoric, provoking an experience in which, like Indra's jewel-net, "all things interpenetrate; that is, each thing contains all things and all 
things contain each thing, such that the entire universe is present in each particular phenomenon." 43

This interpretation sits somewhere between an emphatically visual text and the complex images interlocking architecture, sculpture, and painting which call out for recognition and framework. It suggests that the (probably Kaśmīi) artists and their educated Ladakhi-Tibetan patrons sought to evoke the kūtāagara featured in the GS and in other texts that describe the innermost chamber of mandalas in the slender tower encasing an over-lifesize bodhisattva. They were not necessarily seeking to represent the text itself, but rather, to use recognizable references to the text to simulate and stimulate for the experiencer (I hesitate to write "viewer" since the constricted space and sense of the surrounding also come into play) the enlightening vision which is Sudhana's goal. ${ }^{44}$ The effect is embedded not as discrete content, or meaning, but through the mediation of form, space, and image. While the text describes the "lapislazuli checkerboard" as being found on the walls and floors of a cosmic jeweled tower, the artists would certainly not project sacred scenes onto the floor where they would be impiously, physically walked on. An especially inspired solution was found. The matrix of a repeating textile pattern was activated as appropriate diamond-shaped frames for dozens of narrative scenes wrapped around the huge bodhisattva at eyelevel (figs. 14-16). Scenes of the pilgrim stand in for the past, and eternal ideal in the present, yielding to the present age's Buddha Śākyamuni's past-lives, and are mapped onto the future past-lives of Maitreya. Thus the three times are entwined with the moment of viewing, no one of which is the final point, meaning, or state. The boundaries between the subject and object, the haptic and ornamental, the optical and the representational, the seeable and sayable are unmoored and float into a profound sensory structural model of Buddhist ideals, the fruit savored along the path.

\section{BIBLIOGRAPHY}

\section{Allinger, Eve}

2008 An Early Nepalese Gaṇdavyūhasūtra mansucript: An Attempt to discover connections between text and illuminations, in Claudine Bautze-Picron (ed.), Religion and art: New issues in Indian iconography and iconology (London, British Association for South Asian Studies), pp. 165-178.

Ārya Sūra (J. S. Speyer, trans.)

1895 The Jātakamālā or Garland of birth-stories (London, Henry Frowde).

Benjamin, Walter

2008 The Work of art in the age of its technological reproducibility (second version), in W.

Benjamin, Michael W. Jennings et al. (ed.), The Work of art in the age of its technological

reproducibility, and other writings on media (Cambridge, Belknap Press of Harvard University Press), pp. 19-56.

Brough, John

1964 The Chinese pseudo-translation of Ārya-Śura's Jātaka-Māla, Asia Major 11, no. 1, pp. 28-35. 
Bryner, Edna

1956 Thirteen Tibetan Tankas (Indian Hills, Falcon's Wing Press).

Cleary, Thomas (trans.)

1989 Entry into the realm of reality: The Gandavyuha, the final book of The Avatamsaka sutra (Boston, Shambhala).

Dave-Mukherji, Parul

2001 The Citrasūtra of the Visnudharmottara Purāna (New Delhi, Indira Gandhi National Centre for the Arts/Motilal Banarsidass Publishers).

Dharma Publishing staff (Yeshe De Project, trans.)

1986 The Fortunate aeon: How the thousand Buddhas become enlightened, vol. 2 (Berkeley, Dharma Publishing).

Dunhuang Academy

1982 Zhongguo shiku: Dunhuang mogaoku (Chinese cave series, Dunhuang Mogao grottoes), vol. 1 (Tokyo/Beijing, Heibonsha/Wenwu Chuban She).

Ebert, Jorinde

1994 Niches, columns, and figures in some petroglyphic stūpa depictions of the Karakorum highway, Artibus Asiae, 54, no. 3/4, pp. 268-295.

Emmerick, R. E.

1992 The Sūtra of Golden Light, being a translation of the Suvarṇabhāsottamasūtra (Oxford, Pali Text Society).

Flood, Finbarr B.

2009 Cultural cross-dressing, in Flood (ed.), Objects of translation: Material culture and medieval "Hindu-Muslim" encounter (Princeton, Princeton University Press), pp. 61-87.

Fontein, Jan

2000 Sculpture, text and tradition at Borobudur: A Reconsideration, in Marijke J. Klokke (ed.), Narrative sculpture and literary traditions in South and Southeast Asia (Leiden, Brill), pp. 1-18.

Goepper, Roger

1995 Dressing the temple: Textile representations in the frescoes at Alchi, in Asian Art, $2^{\text {nd }} \mathrm{Hali}$ Annual (London, Worldwide Hali Publications), pp. 100-117, 191.

Grey, Leslie

1994 A Concordance of Buddhist birth stories (Oxford, Pali Text Society).

van Ham, Peter, with contributions by Rob Linrothe, Gerald Kozicz and Amy Heller 2010 Heavenly Himalayas: The Murals of Mangyu and other discoveries in Ladakh (Munich, Prestel).

Hamar, Imre

2007 The History of the Buddhāvatamsaka-Sūtra: Shorter and larger texts, in Hamar (ed.), Reflecting mirrors: Perspectives on Huayan Buddhism (Wiesbaden, Harrassowitz), pp. 139-167.

Heller, Amy

2004 The Lhasa gTsug lag khang: Observations on the ancient wood carvings, Tibet Journal, 29, no.

3, pp. 3-24.

Huntington, Susan L., and John C., Huntington

1990 Leaves from the Bodhi tree: The art of Pāla India ( $8^{\text {th }}-12^{\text {th }}$ centuries) and its international legacy

(Seattle, Dayton Art Institute). 
Khoroche, Peter

1989 Once the Buddha was a monkey: Ārya Śūra's Jātakamālā (Chicago, University of Chicago Press).

Kjaer, Jane

2009 "Hidden textile patterns in Sumda Choon," term paper, Skidmore College, Saratoga Springs, New York.

Klimburg-Salter, Deborah E.

1997 Tabo-A Lamp for the kingdom: Early Indo-Tibetan Buddhist art in the western Himalayas (Milan, Skira, New York, Thames and Hudson).

Krom, N. J.

1927 Barabudur: Archaeological description, 2 vols. (The Hague, Martinus Nijhoff).

Kumari, Ved

1963-73 The Nïlamata Purāna,2 vols (Srinagar, Jammu and Kashmir Academy of Art).

Lamotte, Étienne

[1958] 1967 Histoire du bouddhisme indien : des origines à l'ére Śaka (Louvain, Institut Orientaliste).

Lessing, F. D., and Alex, Wayman

1978 Introduction to the Buddhist tantric systems, translated from Mkhas grub rje's Rgyud sde spyihi rnam par gźag pa rgyas par brjod (Delhi, Motilal Banarsidass).

Linrothe, Rob

1994 The Murals of Mangyu: A Distillation of mature Esoteric Buddhist iconography, Orientations, 25 , no. 11 , pp. 92-102.

Luczanits, Christian

2004 Buddhist sculpture in clay: Early western Himalayan art, late $10^{\text {th }}$ to early $13^{\text {th }}$ centuries (Chicago, Serindia).

1999 The Life of the Buddha in the Sumtsek, Orientations, 30, no. 1, pp. 30-39.

McMahan, David L.

2002 Empty vision: Metaphor and visionary imagery in Mahāyāna Buddhism (London, Routledge Curzon).

2004 Transpositions of metaphor and imagery in the Gandavyūha and Tantric Buddhist practice, Pacific World Journal, $3^{\text {rd }}$ series, no. 6, pp. 181-194.

Naudou, Jean (G. Brereton and Cl . Picron, trans.)

[1968] 1980 Buddhists of Kaśmir (Delhi, Agam Kala Prakashan).

Nou, Jean-Louis and Louis, Fréderic

1996 Borobudur (New York, Abbeville Press).

Osto, Douglas

2009 'Proto-Tantric' elements in the Gandavyūha-sūtra, Journal of Religious History, 33, no. 2, pp. 165-177.

Papa-Kalantari, Christiane

2007 The Art of the court: Some remarks on the historical stratigraphy of eastern Iranian elements in early Buddhist painting of Alchi, Ladakh, in D. Klimburg-Salter, C. Jahoda, and K. Tropper (ed.), Proceeding of the tenth seminar of the IATS, 2003, vol. 7, Text, image and song in transdisciplinary dialogue (Leiden, Brill), pp. 167-228.

2002 The Ceiling paintings of the Alchi gsum brtsegs: Problems of style, in Deborah KlimburgSalter and Eva Allinger (ed.), Buddhist art and Tibetan patronage: Ninth to fourteenth centuries (Leiden, Brill), pp. 85-113. 
Rhys Davids, T. W.

[1880] 2000 Buddhist birth stories: The Oldest collection of folk-lore extant (London, Routledge).

Settar, S.

2003 Hoysala heritage, Frontline, 20, no. 8 (April 12-25), http://www.flonnet.com/fl2008/stories/ $20030425000206700 . h t m$, accessed January 2010.

von Schroeder, Ulrich

2001 Buddhist sculptures in Tibet, vol. 1, India \& Nepal (Hong Kong, Visual Dharma).

Stein, M. A. (trans.)

[1900] 2007 Kalhaṇa's Rājataranginīi, A Chronicle of the kings of Kashmir. vol. 1, Introduction, Books IVII (Srinagar, Gulshan Books).

Steinkellner, Ernst

1995 Sudhana's miraculous journey in the temple of Ta pho: The Inscriptional text of the Tibetan Gandavyūhasūtra (Rome, Istituto Italiano per l'Africa e l'Oriente).

Storm, Mary Nancy

1999 The Heroic image: Self-sacrificial decapitation in the art of India, Ph.D. dissertation, University of California, Los Angeles.

Thakur, Laxman S.

2006 Visualizing a Buddhist sutra: Text and figure in Himalayan art (New Delhi, Oxford University Press).

Tropper, Kurt

2005 Die Jātaka-Inschriften im skor lam chen mo des Klosters Zha lu: Einführung, textkritische Studie, Edition der Paneele 1-8 mit Sanskritparallelen und deutscher Übersetzung (Vienna, Arbeitskreis für Tibetische und Buddhistische Studien Universität Wien).

Tsuda, Shinichi

1982 'Vajrayoșidbhageșu Vijahāra': Historical survey from the beginnings to the culmination of Tantric Buddhism, in L.A. Hercus et al. (ed.), Indological and Buddhist studies volume in honour of Professor J.W. de Jong on his sixtieth birthday (Canberra, Australian National University Press), pp. 595-616.

Wandl, Erna

1999 Textile depictions from the $10^{\text {th }} / 11^{\text {th }}$ Century in the Tabo main temple, in C. A. ScherrerSchaub and E. Steinkellner (ed.), Tabo studies II: Manuscripts, texts, inscriptions, and the arts (Rome, Istituto Italiano per l'Africa e l'Oriente), pp. 277-298.

Wong, Dorothy

2007 The Huayan/Kegon/Hwaŏm paintings in East Asia, in Imre Hamar (ed.), Reflecting mirrors: Perspectives on Huayan Buddhism (Wiesbaden, Harrassowitz), pp. 337-384.

Yukio, Yashiro

1960 Art treasures of Japan, vol. 1 (Tokyo, Kokusai bunka Shinkokai).

\section{NOTES}

1. Measurements follow those of Gerald Kozicz (personal communication, March 22, 2010). My thanks to Melissa Kerin, Peter van Ham, Gerald Kozicz, and Martina D’Alton for constructive comments on a draft of this essay. The western tower's sculpture, also identifiable as Maitreya, no longer has any paintings on its dhoti. 
2. For an introduction to the site as a whole, see van Ham et al. 2010, which on pp. 124-137 includes a much-condensed version of this essay.The paintings of a different shrine at the site were discussed in Linrothe 1994.

3. For a more detailed discussion of the date and stylistic characteristics of the Alchi group, see my "Dating the Mangyu Style," in van Ham et al. 2010, pp. 159-161, 171.

4. Luczanits 2004, pp. 164-167.

5. In my experience at the site, contemporary viewers, especially Westerners, frequently interpret the sculpture as depicting a female figure, since the present view of the chest from below provides the figure with what appear to be swelling breasts. Moreover, this impression has been enhanced by the relatively coarse, and much later, modeling that emphasizes their volume (see figs. 7, 13). However, care must be taken not to project culturally constructed gender coding onto earlier art, and while for contemporary Western viewers, there is a tendency to read the chest as female, in fact the figure bears the standard male bodhisattva hairline and necklaces, as well as a dhoti which is typically asymmetrical in length, shorter on the right leg. Males in the Kaśmīri style ( $k$ ha che lugs) consistently have a straighter hairline, while females have a more rounded hairline, with the hair divided into small cusps, arcs, or curls. The long necklace goes between the breasts on the female figures, to either side on the males. Long tight strands of hair starting behind the ears and flowing onto the shoulders are visible here and in males typically, whereas female figures either have fuller hair at the neck and shoulders, or the hair is virtually veiled with a scarf. Thus the only trait that supports the identification of the figure as female is an ambiguous one, which suggests a figure which can be deemed feminine, but not necessarily female. In fact, a number of undoubtedly male bodhisattva figures made by Kaśmīri artists have similarly swelling chests (von Schroeder 2001, pls. 31B-C, 40B-C, 42B, 52A-F).

6. Typical of Kaśmīri male figures, the dhotī is asymmetrical, falling lower on one side than the other (as often longer on the right as the left). This is seen at other sites in Western Tibet, such as Alchi and Sumda Chung, as well as in sculptures from Kaśmīr proper (see von Schroeder 2001, figs. II-8, 9, 12, pls. 20, 31, 34, 35). Female figures are more apt to have symmetrically long skirts reaching both ankles, as in the Tārā and Prajñāpāramitā paintings in the entrance stūpa with four sculptures at Mangyu (see Linrothe 1994, figs. 10, 12). Parenthetically, this feature helps to underscore the tight connection with Kaśmīr, since the Citrasūtra, attributed to Kaśmīr and the ca. 7th to 9th century specifies of male figures that cloth wrapped around waist should be represented as "extending down to the left knees... the right knee should be exposed" (DaveMukherji 2001, pp. 61-63).

7. Papa-Kalantari 2002, p. 94. For other studies of textiles in Western Tibet at this time, see PapaKalantari 2007, Wandl 1999, Goepper 1995, Flood 2009.

8. Luczanits 2004, p. 167.

9. Grey 1994, pp. 222-224.

10. "This animal seeks to feed on her very own young ones. Hunger causes her to transgress love's law. Alas! Fie upon the ferocity of self-love, that makes a mother wish to make her meal with the bodies of her own offspring!" (Ārya Sūra 1895, p. 4).

11. A perceptive anonymous reviewer pointed out the similarity of this figure with images of the Buddha-to-be cutting off his hair with a sword after the Great Departure. However, in all depictions of the life-story episode known to me, the sword is always held at the level of the hero's hair, not at the neck as here.

12. Identified as such in Settar (2003). For this theme in Indian art and literature, see Storm 1999. She discusses Buddhist literature on self-sacrifice and self-destruction, and briefly mentions the Vyāghrī jātaka, but not the throat-cutting version (pp. 58-60, 98-105).

13. For example, the depiction in Cave 428 at Dunhuang, and the one on the Tamamushi Shrine in the Horyūji Kōndo, Kyoto (see Dunhuang Academy 1982, pls. 168, 169, and Yukio 1960, pls. 40-43). The jātaka also appears in the main circumambulation corridor at Zha lu (see Tropper 
2005, pp. 157-166). My thanks to Dr. Tropper for sending me his photographs of the paintings depicting the jātaka. See also Bryner 1956, pp. 92-111, noticed only after this essay was completed.

14. "On making this decision to be of use to another creature, though it cost him his life, he felt a surge of Joy, then astounded even the calm minds of the gods by hurling himself down. The sound of the Bodhisattva's body as it fell to earth aroused the curiosity and impatience of the tigress. On the point of slaughtering her young, she paused, looked around, and, catching sight of the lifeless corpse, immediately bounded over and began to devour it." (Khoroche 1989, p. 8).

15. Emmerick 1992, pp.92-105. This text has three Tibetan versions, the second one by Jinamitra, Śīlendrabodhi and Yes śes sde (see ibid., p. xii). Jinamitra and Śilendrabodhi are identified as Kaśmiri of the ca. late $8^{\text {th }}$-early $9^{\text {th }}$ century, which doesn't prove that the SS necessarily circulated in Kaśmir, but it is an indication that it did, and so its precise themes would be familiar to the artists who painted at Mangyu (see Naudou ([1968] 1980, p. 100). Lamotte notes that already in the Maurya period, "Sur le Haut Indus, le prince Mahāsattva avait livré son corps à une tigresse affamée" ([1958] 1967, p. 367). Interestingly, the previously translated SS version of the tigress story as translated into Chinese by Yijing (635-713) was used for a purported Chinese Song-period translation of Ārya Śūra's Jātakamāla, Brough 1964.

16. Emmerick 1992, verses 214,215 , p. 97. In that telling of the narrative, there is no mountain involved, but later in the same chapter, the verse summary tells that Mahāsattva "fell down the mountain-side, when he saw the hungry tigress, in order to save the cubs of the tigress, out of compassion" (Emmerick 1992, verse 227, p. 101). A painting on cloth in the Buryat Historical Museum of the ca. $19^{\text {th }}$ century depicts a bleeding figure of the Buddha-to-be lying down in front of the tigress and her cubs, holding a stick in his right hand, and no obvious cliff in the image (see image number 74281 on the Himalayan Art Resources website, www.himlayanart.org, accessed September 2010).

17. Ārya Śūra's version mentions that the Gandharvas, Yakṣas, Nāgas, and devas offered reverence to his bones $(1895$, p. 7). In the SS, Śakyamuni reveals that he was Mahāsattva, and his eldest brother Mahāpranāa was Maitreya (see Emmerick 1992, verse 240, p. 105).

18. Nou and Fréderic 1996, IBa.1-4, p. 314.

19. For this observation I am indebted to Kjaer 2009.

20. Luczanits 1999. The same point is made in the Bhadrakalpa Sütra (see Dharma Publishing staff 1986, pp. 521-23).

21. This is true at least for the phase of Esoteric Buddhism most relevant for the Alchi group of monuments, and the related texts known as Yoga Tantra. See Lessing and Wayman 1978, pp. 27-29. There, Khedrup Je cites the commentaries of Śakyamitra, Buddhaguhya and Ānandagarbha on the Sarva-Tathāgata-Tattvasamgraha which disagree on some points but are united in asserting that the Buddhas of the ten directions brought the Bhagavat's mental body (manomaya-kāya) to Akanisth ha heaven where he received the diadem initiation from them, while his maturation body (vipāka-kāya) remained at Bodh Gaya. Only then did the Buddha become Mahāvairocana at the sambhoga-kāya level.

22. "Now whilst he was still seated there... the Blessed One thought, 'It is in order to attain to this throne of triumph that I have undergone successive births for so long a time, that I severed my crowned head from my neck and gave it away, that I tore out my darkened eyes and my heart's flesh and gave them away" " (Rhys Davids [1880] 2000, p. 105, emphasis added).

23. Klimburg-Salter 1997, Thakur 2006. These murals are also briefly, if insightfully discussed by Dorothy Wong; however, she comes to the arguable conclusion that the "unusual arrangement there [at Tabo Monastery Dukhang] of individual scenes accompanied by panels of text comes more from the Chinese than the Indian tradition " (Wong 2007, p. 353). 
24. Heller 2004. It is mentioned in inscriptions in, notably, the Maitreya lhakhang of the Gyantse dPal 'khor chos sde sku 'bum as well as in the bSam 'phel rin po che lha khang in the fort (see Tropper 2005, pp. 56, 59, 61).

25. Allinger 2008.

26. Krom 1927, pp. 1-64, Nou and Fréderic 1996, pp. 252-77.

27. Steinkellner suggests that the text of the Tabo GS was based on the translation of the text by a team including Jinamitra, Surendrabodhi, and Ye ses sde at the beginning of the $9^{\text {th }}$ century (see Steinkellner 1995, p. 14), and note 15 above. The latest of four translations into Chinese was also done by a Kaśmīri monk, Prajñā, in 798, though he worked from a manuscript sent to the Tang emperor by King Subhakara of Kalinga (Orissa). See Osto 2009, pp. 166-167, also Hamar 2007.

28. Compare with the style of Kaśmīri and Gilgit stūpas illustrated in Ebert 1994, pp. 268-95, esp. pls. 31, 4, 25, 27 and fig. 11.

29. Among the many panels devoted to the GS at Borobudur, at least three scenes occur of the worship of stūpas by one or more people including Sudhana and his teachers (Nou and Fréderic 1996, II.45 p. 256, II.96 p. 263 and II.98 p. 264). A similar scene of worship of an image of the Buddha with stūpas in the background was originally part of a manuscript from Nepal dating to around the $12^{\text {th }}$ century, contemporary with the Mangyu paintings. The leaf in question is in the Seattle Art Museum; for an illustration see Huntington and Huntington 1990, fig. 26, p. 261. The thirty-eight known leaves of the manuscript have been masterfully treated in Allinger 2008.

30. Nou and Fréderic 1996, II.42 p. 256.

31. These figures in their dress and ornament resemble the more spectacular Tārā and Prajñāpārāmitā figures at the Alchi Sumtsek, and correspond closely to a passage in the Kaśmīri royal chronicle, the Rājataranginī describing Harșa's ladies who "wore long garlands formed by their hair-braids into which were [woven] golden Ketaka-leaf [ornaments]; the pendants which they wore over their forehead-marks made the latter unsteady; they joined the corners of their eyes with their ears by a line drawn with colyrium; into the ends of their locks which were not veiled, were twined golden strings; with the hanging-down train of their lower garments they kissed the ground; their breasts were dressed in jackets which covered [but] half the length of their arms" (Stein [1900] 2007, p. 340).

32. Eva Allinger has also noted discrepancies between the textual description and the illustrations (2008, p. 157, regarding her fig. 10).

33. For example, the night-goddess Sarvanagara-rakșāsaṃbhava-tejaḥśrī is described as having "a body guiding all beings to ultimate perfection" (Cleary 1989, p. 215) while she herself says that "I teach sentient beings with wisdom consisting of learning" (ibid., p. 217) and states that she establishes sentient beings in "the perfection of wisdom [called] 'entry into the principles of the ocean of all truths"” (ibid., p. 219).

34. Steinkellner 1995, p.13. For the relevant murals described, inscriptions transcribed and summarized (see ibid., pp. 91-101).

35. Fontein 2000, p. 12.

36. In Cleary's translation, this chapter requires fifty-one pages (1989, pp. 328-378).

37. Another translation is "the great pavilion of the storehouse of the ornaments of Vairocana" (Tsuda 1982, p.600). In his explication of the GS, Samantabhadra, Mañjuśrī, Maitreya and Vairocana are closely linked (ibid., pp. 600-602).

38. Cleary 1989, pp. 369-370.

39. Ibid., p. 371.

40. Ibid. In the Tabo illustrations, some of the narratives are actually labeled as jātakas though they specifically mention the Viśvantara jātaka, not the Vyāghrī. See Steinkellner 1995, pp. 91-92.

41. A similar observation on the status of Sudhana is made by Dorothy Wong, who sees Sudhana's visit becoming "an enduring metaphor of the prototypical pilgrimage central to the Buddhist concept of soteriology" (Wong 2007, p. 354). In the Nilamata Purāna (another text 
associated with Kaśmīr, datable to the ca. $6^{\text {th }}$ to $7^{\text {th }}$ century), kūtāgāra seem to be understood as mobile towers, temporary processional chariot-cars for the deities. See Kumari 1968-1973, vol. 2, verses 891-896, pp. 226-227.

42. Following Fontein who suggests that, as artists would have had greater access to narratives, oral and textual, some of which may not have been transmitted to present times, "[a]s a matter of principle it would seem much safer to assume, even if only as a working hypothesis, that we are the ones who are making the mistakes and that we misunderstand things, instead of attributing similar shortcomings to the artists." (Fontein 2000, p. 10).

43. McMahan 2002, p. 134. His treatment of the episode of Maitreya's tower as a vision provoked through textual rhetoric was inspirational for its extension here into the visual realm. See also McMahan 2004.

44. "Buildings are received in a twofold manner: by use and by perception. Or, better: tactilely and optically. Such reception cannot be understood in terms of the concentrated attention of a traveler before a famous building." (Benjamin 2008, p. 40).

\section{ABSTRACTS}

This essay explores the image-text relationship between the ca. 12-century monumental Maitreya bodhisattva sculpture within a narrow tower in the village of Mangyu and passages from the Gandavyūha Sūtra. Paintings on the dhotī of the sculpture resemble themes described within a kūtāgāra-tower in the text related to Maitreya, and also depict one of the prominent jātaka associated with the Buddha, the Starving Tigress, or Vyāghrī jātaka. The essay suggests the jātaka was deployed to demonstrate Maitreya's recapitulation of the course of Śākyamuni's path of self-sacrifice, and that the resemblance between text and image was intentional on the part of the 12th-century builders in Ladakh, on the far western reaches of cultural Tibet.

Cet essai étudie la relation entre image et texte en se fondant sur la scuplture monumentale du bodhisattva Maitreya (xII ${ }^{\mathrm{e}}$ siècle) placée dans une étroite tour du village de Mangyu et des passages du Gandavyūha Sūtra. Des peintures sur le dhotī de la sculpture rappellent des thèmes décrits à l'intérieur d'une tour-kūtāgāra dans le texte concernant à Maitreya et dépeint également l'un des célèbres jātaka associé au Bouddha, celui de la tigresse affamée ou Vyāghrī jātaka. Cet article suggère que le jātaka a été mis en œuvre pour retracer le chemin qui a mené le Bouddha à l'auto-sacrifice et aussi que les artistesdu XII ${ }^{\mathrm{e}}$ siècle au Ladakh, à l'extrême ouest de l'aire culturelle tibétaine, ont intentionnellement souligné la ressemblance entre image et texte.

\section{INDEX}

Geographical index: Ladakh, Tibet

Keywords: Mangyu, clothes, painting, sculpture, Buddha

Mots-clés: Mangyu, vêtements, peinture, sculpture, Bouddha 


\section{AUTHOR}

\section{ROB LINROTHE}

Rob Linrothe est assistant professeur d'histoire de l'art à la Northwestern University (USA). Il est l'auteur et l'éditeur d'articles, de livres et de catalogues sur l'art himalayen, dont Holy Madness: Portraits of Tantric Siddhas (2006). Il travaille actuellement sur un livre intitulé At Shambhala Gate: Towards an Art History of Zangskar qui traite de l'art du Zangskar, dans cette région indienne de culture tibétaine. 